Key Words:

Vadose Zone

PORFLOW

Performance Assessment

Retention:

Permanent

\title{
Evaluation of E-Area Slit Trench Performance Under As-Filled Conditions
}

Prepared by:

Gregory P. Flach

Margaret R. Millings

June 2003

Westinghouse Savannah River Company

Savannah River Site

Aiken, SC 29808

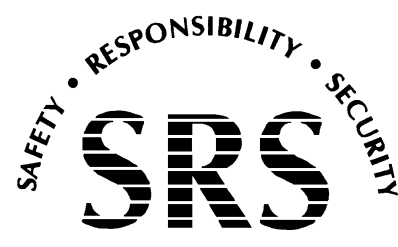

SAVANNAH RIVER SITE

Prepared for the U.S. Department of Energy Under

Contract Number DE-AC09-96SR18500 
This document was prepared in conjunction with work accomplished under Contract No. DE-AC09-96SR18500 with the U. S. Department of Energy.

\section{DISCLAIMER}

This report was prepared as an account of work sponsored by an agency of the United States Government. Neither the United States Government nor any agency thereof, nor any of their employees, makes any warranty, express or implied, or assumes any legal liability or responsibility for the accuracy, completeness, or usefulness of any information, apparatus, product or process disclosed, or represents that its use would not infringe privately owned rights. Reference herein to any specific commercial product, process or service by trade name, trademark, manufacturer, or otherwise does not necessarily constitute or imply its endorsement, recommendation, or favoring by the United States Government or any agency thereof. The views and opinions of authors expressed herein do not necessarily state or reflect those of the United States Government or any agency thereof.

This report has been reproduced directly from the best available copy.

Available for sale to the public, in paper, from: U.S. Department of Commerce, National Technical Information Service, 5285 Port Royal Road, Springfield, VA 22161, phone: (800) 553-6847, fax: (703) 605-6900

email: orders@ntis.fedworld.gov

online ordering: http://www.ntis.gov/help/index.asp

Available electronically at http://www.osti.gov/bridge

Available for a processing fee to U.S. Department of Energy and its contractors, in paper, from: U.S. Department of Energy, Office of Scientific and Technical Information, P.O. Box 62, Oak Ridge, TN 37831-0062,

phone: (865)576-8401,

fax: (865)576-5728

email: $\underline{\text { reports@ adonis.osti.gov }}$ 
Key Words:

Modeling

PORFLOW

Performance Assessment

Retention:

Permanent

\section{Evaluation of E-Area Slit Trench Performance Under As-Filled Conditions}

Prepared by:

Gregory P. Flach

Margaret R. Millings

June 2003

Westinghouse Savannah River Company

Savannah River Site

Aiken, SC 29808

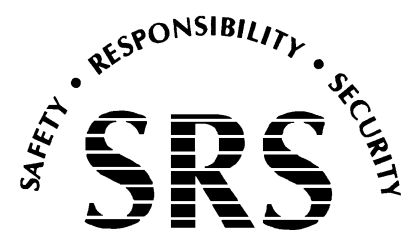

SAVANNAH RIVER SITE

Prepared for the U.S. Department of Energy Under

Contract Number DE-AC09-96SR18500 
This page intentionally left blank 


\section{Executive Summary}

Waste acceptance criteria (WAC) for the E-Area Slit Trenches are based on a Performance Assessment (PA) and subsequent Special Analyses. Because the PA was first performed prior to operation of the Slit Trenches, the eventual waste distribution and forms were unknown and hypothetical waste loading scenarios were analyzed. Generally each radionuclide was assumed to be uniformly distributed throughout the area covered by Slit Trenches \#1 and \#2, and reside in a solid waste form that results in an instantaneous leaching of the entire inventory to soil moisture in trenches. Slit Trenches \#1 are now nearly full, and thus the actual distribution and form of solid wastes buried there are approximately known. This Special Study assesses the performance of E-Area Slit Trenches under as-filled conditions in Slit Trenches \#1, and compares predicted peak aquifer concentration to PA results. Results are limited to tritium, which is the dominant contributor to the current sum-of-fractions for Slit Trenches \#1.

In Slit Trenches \#1, tritium comprised $85 \%$ of the sum-of-fractions through $4 / 16 / 03$, and $82 \%$ of the H-3 inventory is associated with $232-\mathrm{F}$ D\&D operations. Tritium activity from $232-\mathrm{F}$ is concentrated primarily in trench compartments 14-1B and 14-1C with a combined length of approximately $200 \mathrm{ft}$. In this area, the tritium density $\left(\mathrm{Ci} / \mathrm{ft}^{2}\right)$ is roughly 10 times higher than the average. Although non-uniform, the as-filled distribution of tritium inventory in Slit Trenches \#1 is not expected to result in peak concentrations that are significantly higher than a uniform distribution, as assumed in the PA. This conclusion is specific to the particular distribution of tritium in Slit Trenches \#1.

Solid waste from 232-F is substantially in the form of concrete rubble. As discussed by Hochel and Clark (2003), tritium embedded within such concrete is expected to leach to trench soil moisture much more slowly than assumed in PA modeling. This study indicates the peak fractional flux to the water table would be approximately 4 times lower for tritium in cementitious wastes compared to instantaneous leaching. Corresponding peak $\mathrm{H}-3$ groundwater concentrations are about 3 times lower for cementitious (e.g. 232-F) wastes. Consideration of waste form could offer an important opportunity to reduce conservatism in PA-based Waste Acceptance Criteria for tritium or other radionuclides. 


\section{Table of Contents}

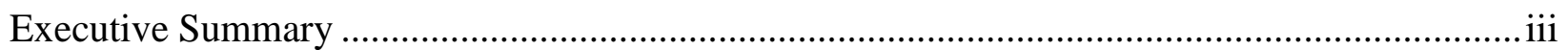

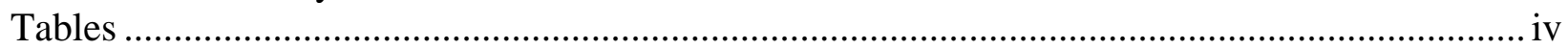

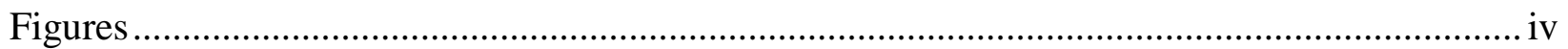

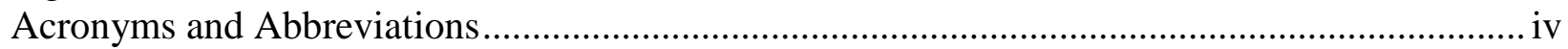

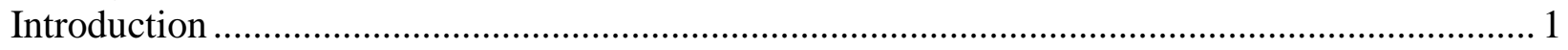

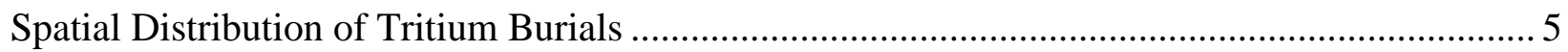

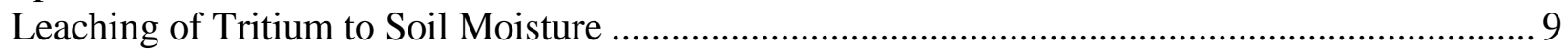

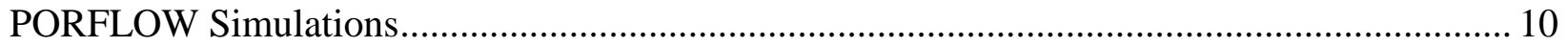

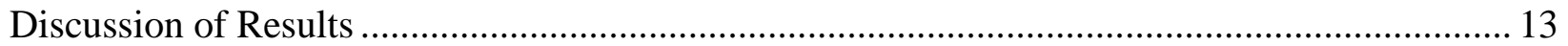

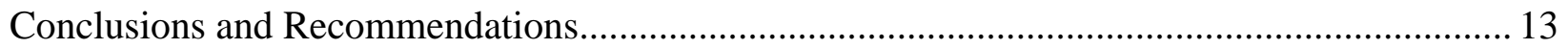

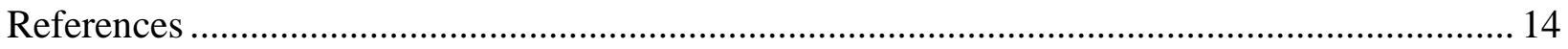

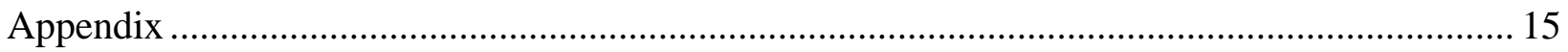

\section{Tables}

Table 1. Isotopes contributing greater than $1 \%$ of the PA limit to the sum-of-fractions for Slit Trenches \#1 on 4/16/2003 ............................................................................ 2

Table 2. Approximate as-filled distribution of H-3 in Slit Trenches \#1 ................................. 6

Table 3. Model distribution of H-3 in Slit Trenches \#1 and \#2 for the as-filled scenario ........... 6

Table 4. Aquifer transport scenarios considered ..................................................................... 11

Table 5. Peak concentration results of aquifer transport simulation .......................................... 11

\section{Figures}

Figure 1. Slit Trenches \#1 and \#2 and corresponding representation in the aquifer (saturated zone) PORFLOW transport model........................................................................ 2

Figure 2. Computational grid for Point Source Special Study (reproduced from WSRC-TR-2002-00117) ............................................................................... 3

Figure 3. Comparison of PA and Point Source Special Study models; (a) plan view; (b) crosssectional view (reproduced from WSRC-TR-2002-00117) ........................................... 4

Figure 4. Approximate relative distribution of tritium burials in Slit Trenches \#1 ....................... 7

Figure 5. Slit Trenches \#1 and \#2 as represented in the PORFLOW aquifer model..................... 8

Figure 6. Fractional release of tritium from the bottom of a slit trench based on Hochel and

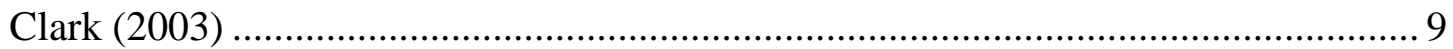

Figure 7. Fractional fluxes of tritium from the bottom of a slit trench and at the water table for:

(a) Rapid (PA) release and (b) Hochel and Clark (2003) release.

\section{Acronyms and Abbreviations}

D\&D Decontamination and Decommissioning

LAW Low Activity Waste

PA Performance Assessment

$\mathrm{pCi} / \mathrm{L}$ picocuries per liter

WAC Waste Acceptance Criteria

WITS Waste Information Tracking System

WSRC Westinghouse Savannah River Company 


\section{Introduction}

Waste acceptance criteria (WAC) for the E-Area Slit Trenches are based on a Performance Assessment (PA) and subsequent Special Analyses (WSRC 2002; McDowell-Boyer et al. 2000; Cook 2002). Because the PA was first performed prior to operation of the Slit Trenches, the eventual waste distribution and forms were unknown and hypothetical waste loading scenarios were analyzed. Generally each radionuclide was assumed to be uniformly distributed throughout the area covered by Slit Trenches \#1 and \#2 (Figure 1), and reside in a solid waste form that results in an instantaneous leaching of the entire inventory to soil moisture in trenches.

Slit Trenches \#1 are now nearly full, and thus the actual distribution and form of solid wastes buried there are approximately known. The purpose of this Special Study is to assess the performance of E-Area Slit Trenches under as-filled conditions in Slit Trenches \#1, and compare predicted peak aquifer concentration to PA results.

Table 1 lists isotopes contributing greater than $1 \%$ of the PA limit to the sum-of-fractions as of 4/16/03. The total sum-of-fractions for Slit Trenches \#1 was 0.882 on 4/16/03, so other isotopes only contribute an additional 0.028 to the 0.854 impact in Table 1 . Tritium is the dominant contributor to the sum-of-fractions, comprising $85 \%(0.748 \div 0.882)$. Because tritium effectively controls the performance of Slit Trenches \#1, only tritium is considered for further analysis.

In a recent "Point Source" study, Collard (2002) analyzed the effects of hypothetical nonuniform waste inventory distributions for I-129 in two forms. Because the PA aquifer model grid (Figure 1) was too coarse to represent point sources down to the desired scale of 4 individual B25 boxes (4' depth $\times$ 4' height $\times$ 6' width for each box), a higher-resolution, local-scale flow and transport model was developed (Figure 2). The PA and Point Source models are compared in Figure 3. For consistency with the prior analysis of non-uniform waste loadings, the models and analysis approach developed by Collard (2002) were adopted as the starting point for the present Special Study of as-filled conditions.

In the sections that follow, the spatial distribution of tritium inventory in Slit Trenches \#1 is estimated from Waste Inventory Tracking System (WITS) data and facility operation information under as-filled conditions through 4/16/03 (Sink 2003; Appendix). An alternative model of tritium release from the bottom of a slit trench, more appropriate for the cementitious form of 232-F burials, is considered based on the work of Hochel and Clark (2003). Results from PORFLOW (Analytical \& Computational Research Inc. 2000) vadose and saturated zone simulations using the as-filled spatial distribution and trench release model are then compared to the PA and related simulations. 
Table 1. Isotopes contributing greater than $1 \%$ of the PA limit to the sum-of-fractions for Slit Trenches \#1 on 4/16/2003.

\begin{tabular}{|l|c|c|c|}
\hline $\begin{array}{l}\text { Primary Isotopes Of } \\
\text { Concem }\end{array}$ & $\begin{array}{c}\text { Sit Trenches \#1 } \\
\text { Activity } \\
\text { (Ci) }\end{array}$ & $\begin{array}{c}\text { Sit Trenches PA } \\
\text { Limit } \\
\text { (Ci) }\end{array}$ & $\begin{array}{c}\text { Fraction Of } \\
\text { PA limit }\end{array}$ \\
\hline H3 & $4.71 \mathrm{E}+00$ & $6.3 \mathrm{E}+00$ & $7.48 \mathrm{E}-01$ \\
I129 F Area Filterc a ke & $8.14 \mathrm{E}-05$ & $3.2 \mathrm{E}-03$ & $2.55 \mathrm{E}-02$ \\
NP237 & $1.09 \mathrm{E}-03$ & $4.8 \mathrm{E}-02$ & $2.26 \mathrm{E}-02$ \\
C14 & $6.09 \mathrm{E}-02$ & $2.7 \mathrm{E}+00$ & $2.25 \mathrm{E}-02$ \\
I129 Generic & $1.87 \mathrm{E}-05$ & $1.0 \mathrm{E}-03$ & $1.87 \mathrm{E}-02$ \\
U238 & $1.24 \mathrm{E}-01$ & $7.4 \mathrm{E}+00$ & $1.67 \mathrm{E}-02$ \\
\hline \multicolumn{3}{|r}{} \\
\hline
\end{tabular}

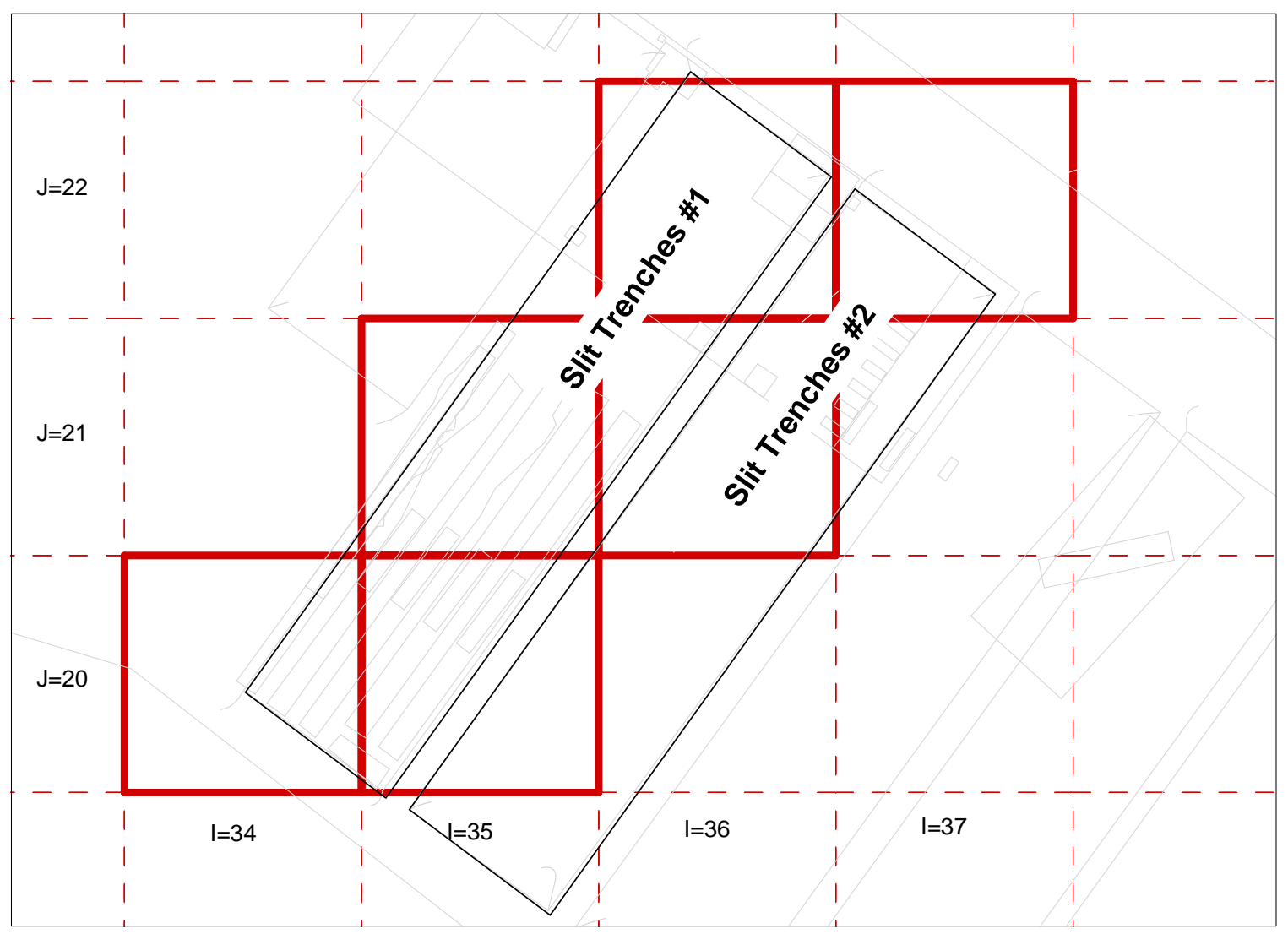

Figure 1. Slit Trenches \#1 and \#2 and corresponding representation in the aquifer (saturated zone) PORFLOW transport model. 


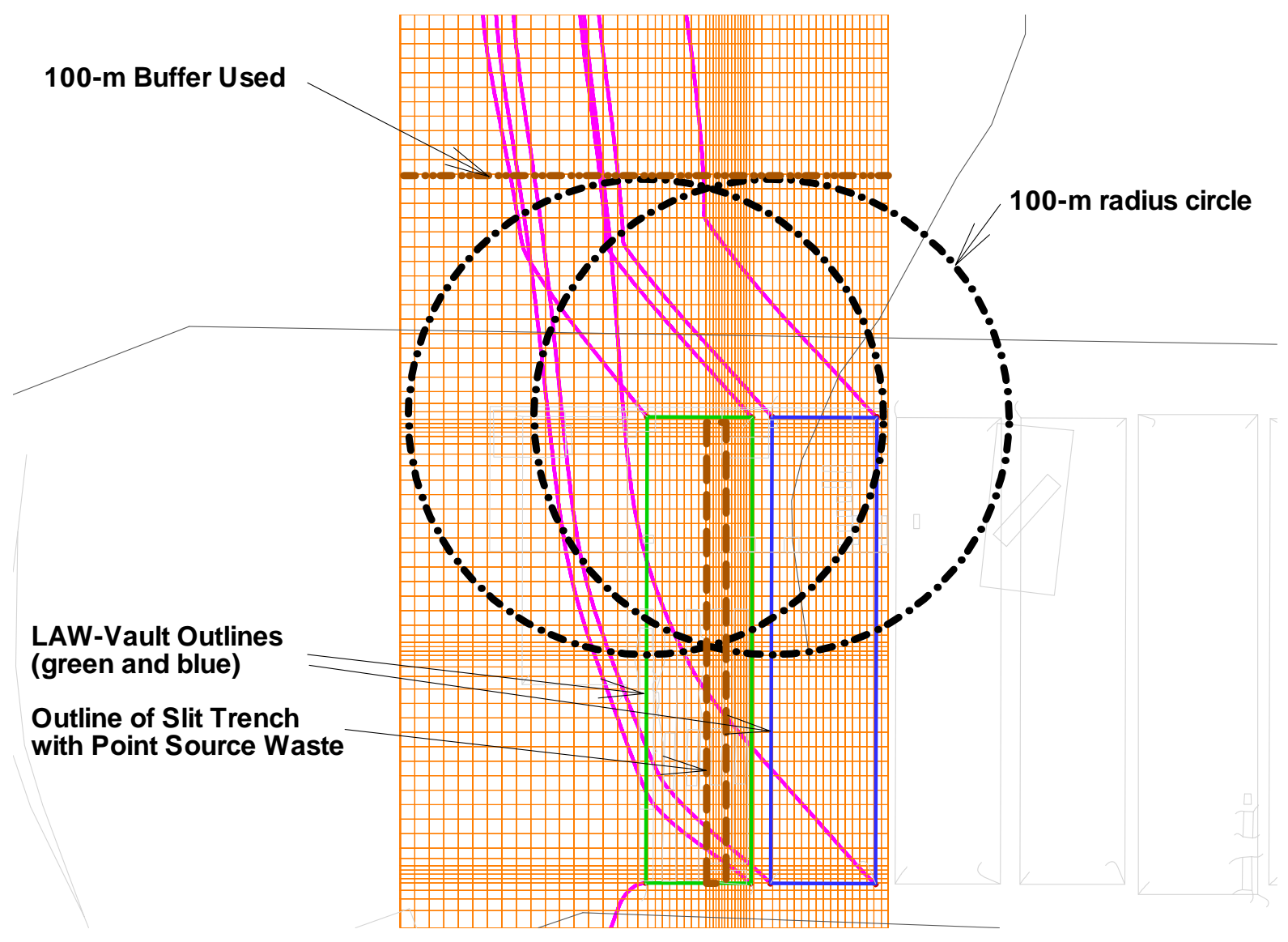

Figure 2. Computational grid for Point Source Special Study (reproduced from WSRC-TR-2002-00117). 


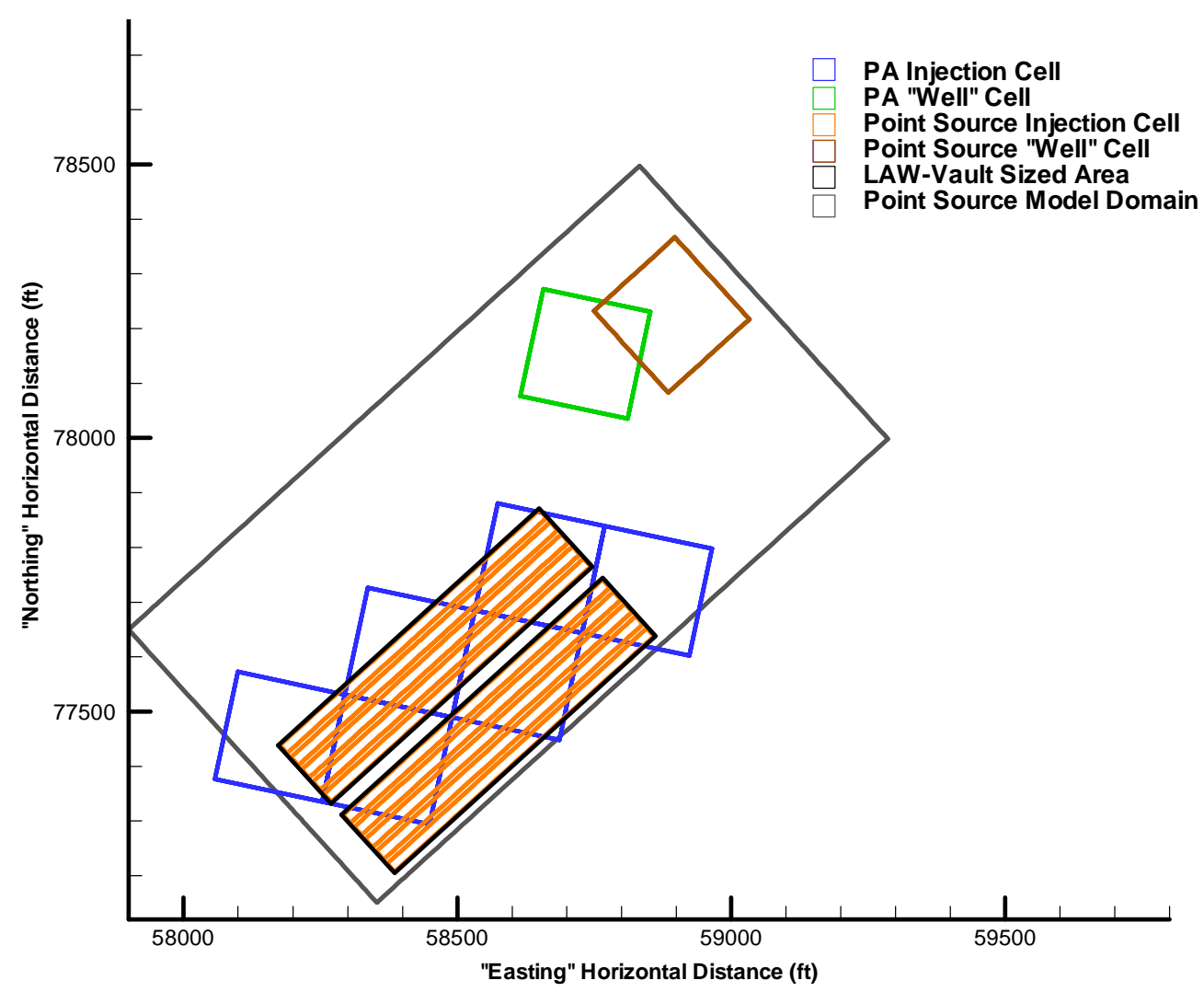

(a)
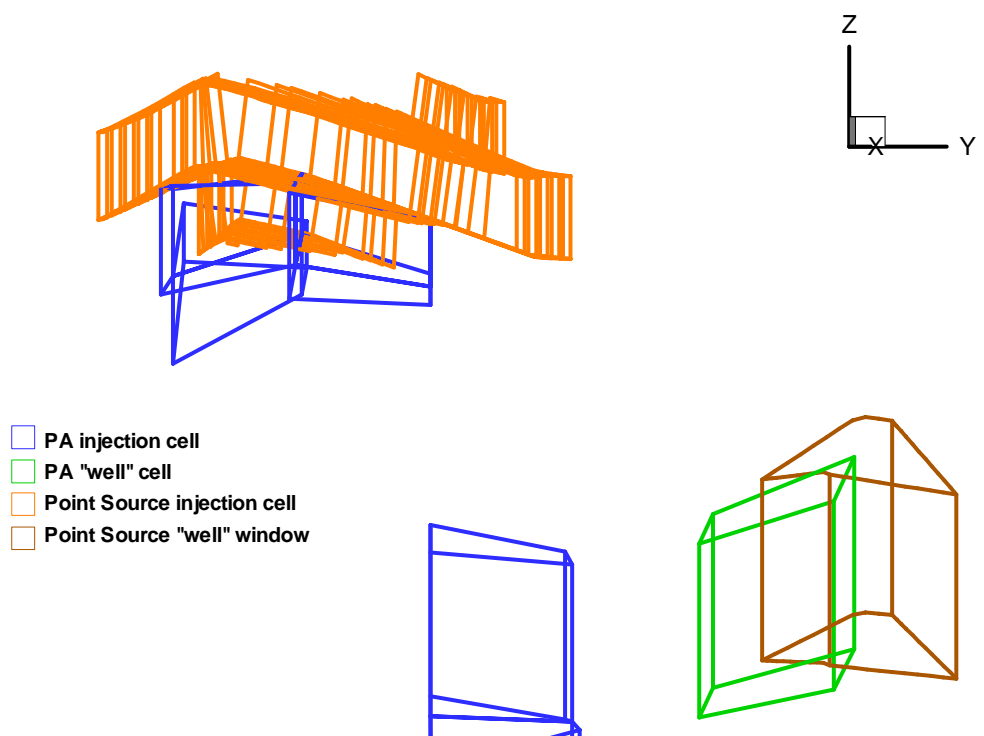

(b)

Figure 3. Comparison of PA and Point Source Special Study models; (a) plan view; (b) cross-sectional view (reproduced from WSRC-TR-2002-00117). 


\section{Spatial Distribution of Tritium Burials}

The main source of tritium in Slit Trenches \#1 originates from 232-F D\&D operations. According to the Waste Information Tracking System (WITS) and operations records, portions of Slit Trenches 14-1 and 14-2 within Slit Trenches \#1 received 237 packages of 232-F building rubble with a total activity of $3.90 \mathrm{Ci}$. Waste stream calculations indicate that tritium $(\mathrm{H}-3)$ accounts for $99.28 \%$ of the total activity, or $3.87 \mathrm{Ci}$. As of $4 / 16 / 03$, the total tritium inventory in Slit Trenches \#1 was $4.71 \mathrm{Ci}$ (Sink 2003). Burials associated with 232-F D\&D thus comprise $82 \%$ of the total through that date.

WITS data and facility operation information provided by D. Sink and S. Reed (Sink 2003; Appendix) were used to determine the relative as-filled distribution of tritium in Slit Trenches \#1. Four individual compartments received waste from 232-F D\&D Rubble operations: 14-1B, 14-1C, 14-2A, and 14-2B (Figure 4). Documented activities from the individual shipments of waste were assigned to the slit trench compartments based on the dates of operation of the compartments. For example, 14-1B operated in January of 1997 therefore 232-F D\&D shipments received for December 1996 and January 1997 were assumed to have been buried in this compartment. For each compartment, the total activity from these waste shipments was multiplied by $99.28 \%$ to estimate a tritium activity. Tritium not associated with $232-\mathrm{F}$ D\&D $(0.84 \mathrm{Ci}$ or $18 \%)$ was assumed to be uniformly distributed through the remaining area. The tritium activity for each compartment was then compared to the average tritium density calculated for Slit Trenches \#1 to obtain a relative tritium distribution.

Table 2 summarizes the data used to determine the relative tritium distribution (relative density) depicted in Figure 4. Slit trench compartments 14-1B and 14-1C contain the highest concentration of tritium, with average activities per area that are 8.6 and 12.7 times higher than the average density for Slit Trenches \#1. Over the remaining trench area, the density of H-3 is approximately 0.2 times the average loading.

In the prior Point Source study, Slit Trenches \#1 and \#2 were assumed to be comprised of 10 individual trenches, each $20 \mathrm{ft}$ wide by $640 \mathrm{ft}$ long (Figure 3a). The gap between trenches was 10 $\mathrm{ft}$. The Point Source model representation is similar to the actual trench configuration in Slit Trenches \#1 and adequate for the present study. For consistency, the same representation of slit trenches is used for PORFLOW modeling in this study.

Figure 5 shows the model representation of Slit Trenches \#1 and \#2 in greater detail, and identification labels for each trench or trench segment defined in modeling. The analysis shown in Table 2 was repeated for the modeled trench configuration to account for differences in geometry between Figures 4 and 5. Also, the PA assumes that tritium is uniformly distributed between Slit Trenches \#1 and \#2, and this assumption is retained in the current analysis. The activity estimated to reside in each physical compartment identified in Table 2 is preserved in the model representation of the same compartment. The results for a $1 \mathrm{Ci}$ total inventory are summarized in Table 3. Note that the physical area of Slit Trenches \#1 is approximately 52,000 $\mathrm{ft}^{2}$, compared to $64,000 \mathrm{ft}^{2}$ for the same trenches as modeled. The area difference leads to differences in the relative density factors listed in Tables 2 and 3 (e.g. 12.7 versus 15.2 for compartment 14-1C). 
Table 2. Approximate as-filled distribution of H-3 in Slit Trenches \#1.

\begin{tabular}{lcccccccc}
\hline $\begin{array}{c}\text { Slit Trench } \\
\text { Compartments }\end{array}$ & $\begin{array}{c}\text { Start of } \\
\text { Shipments }\end{array}$ & $\begin{array}{c}\text { End of } \\
\text { Shipments }\end{array}$ & $\begin{array}{c}\text { Vol of Waste } \\
\text { Received }\left(\mathrm{m}^{3}\right)\end{array}$ & $\begin{array}{c}\text { Tritium } \\
\text { Activity }(\mathrm{Ci})\end{array}$ & $\begin{array}{c}\text { \% of Total } \\
\text { Tritium } \\
\text { Activity }\end{array}$ & Area (ft $\left.{ }^{2}\right)$ & $\begin{array}{c}\text { Activity /Area } \\
\left(\mathrm{Ci} / \mathrm{ft}^{2}\right)\end{array}$ & $\begin{array}{c}\text { Relative } \\
\text { density }\end{array}$ \\
\hline \hline Total for LAW Vault 14 & & & 4.7100 & $100 \%$ & 51909 & $9.07 \mathrm{E}-05$ & \\
\hline 14-1B & $12 / 96$ & $01 / 97$ & 174 & 1.5491 & $32.89 \%$ & 1978 & $7.83 \mathrm{E}-04$ & 8.6 \\
$14-1 \mathrm{C}$ & $02 / 97$ & $03 / 97$ & 775 & 2.0376 & $43.26 \%$ & 1767 & $1.15 \mathrm{E}-03$ & 12.7 \\
$14-2 \mathrm{~A}$ & $04 / 97$ & $05 / 97$ & 441 & 0.2822 & $5.99 \%$ & 2122 & $1.33 \mathrm{E}-04$ & 1.5 \\
$14-2 \mathrm{~B}$ & $06 / 97$ & $06 / 97$ & 194 & $2.88 \mathrm{E}-04$ & $0.01 \%$ & 2083 & $1.38 \mathrm{E}-07$ & 0.002 \\
\hline
\end{tabular}

Table 3. Model distribution of $\mathbf{H - 3}$ in Slit Trenches \#1 and \#2 for the as-filled scenario. Slit Trenches \#1

\begin{tabular}{|c|c|c|c|c|c|c|c|c|c|c|c|c|}
\hline ID & Alias & Length & Area & 232-F? & $\begin{array}{c}\text { 232-F } \\
\text { Activity }\end{array}$ & Area & $\begin{array}{c}\text { Area } \\
\text { Fraction }\end{array}$ & $\begin{array}{c}\text { Other } \\
\text { Activity }\end{array}$ & $\begin{array}{c}\text { Total } \\
\text { Activity }\end{array}$ & $\begin{array}{l}\text { Activity } \\
\text { Fraction }\end{array}$ & For $0.5 \mathrm{Ci}$ Total & $\begin{array}{l}\text { Relative } \\
\text { Density }\end{array}$ \\
\hline 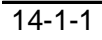 & & 188 & 3760 & $\mathrm{n}$ & & 3760 & $6.7 \%$ & 0.0563 & 0.0563 & $1.2 \%$ & 0.0060 & 0.20 \\
\hline $14-1-2$ & 14-1B & 97 & 1940 & $y$ & 1.5491 & & & & 1.5491 & $32.9 \%$ & 0.1644 & 10.85 \\
\hline $14-1-3$ & $14-1 C$ & 91 & 1820 & $y$ & 2.0376 & & & & 2.0376 & $43.3 \%$ & 0.2163 & 15.21 \\
\hline $14-1-4$ & & 264 & 5280 & $n$ & & 5280 & $9.4 \%$ & 0.0790 & 0.0790 & $1.7 \%$ & 0.0084 & 0.20 \\
\hline $\begin{array}{l}14-2-1 \\
\end{array}$ & & 24 & 480 & $\mathrm{n}$ & & 480 & $0.9 \%$ & 0.0072 & 0.0072 & $0.2 \%$ & 0.0008 & 0.20 \\
\hline $14-2-2$ & $14-2 \mathrm{~A}$ & 104 & 2080 & $y$ & 0.2822 & & & & 0.2822 & $6.0 \%$ & 0.0300 & 1.84 \\
\hline $14-2-3$ & $14-2 B$ & 100 & 2000 & $y$ & 0.0003 & & & & 0.0003 & $0.0 \%$ & 0.0000 & 0.00 \\
\hline $14-2-4$ & & 412 & 8240 & $\mathrm{n}$ & & 8240 & $14.7 \%$ & 0.1234 & 0.1234 & $2.6 \%$ & 0.0131 & 0.20 \\
\hline $14-3$ & & 640 & 12800 & $\mathrm{n}$ & & 12800 & $22.8 \%$ & 0.1916 & 0.1916 & $4.1 \%$ & 0.0203 & 0.20 \\
\hline $14-4$ & & 640 & 12800 & $\mathrm{n}$ & & 12800 & $22.8 \%$ & 0.1916 & 0.1916 & $4.1 \%$ & 0.0203 & 0.20 \\
\hline $14-5$ & & 640 & 12800 & $\mathrm{n}$ & & 12800 & $22.8 \%$ & 0.1916 & 0.1916 & $4.1 \%$ & 0.0203 & 0.20 \\
\hline \multirow[t]{2}{*}{ Total } & & & 64000 & & 3.87 & 56160 & $100.0 \%$ & 0.84 & 4.71 & $100.0 \%$ & 0.5000 & \\
\hline & & & & Tot & 4.71 & & & & & & & \\
\hline
\end{tabular}

Slit Trenches \#2

\begin{tabular}{|c|c|c|c|c|c|c|c|c|c|c|c|c|}
\hline ID & Alias & Length & Area & 232-F? & $\begin{array}{c}232-\mathrm{F} \\
\text { Activity }\end{array}$ & Area & $\begin{array}{c}\text { Area } \\
\text { Fraction }\end{array}$ & $\begin{array}{c}\text { Other } \\
\text { Activity }\end{array}$ & $\begin{array}{c}\text { Total } \\
\text { Activity }\end{array}$ & $\begin{array}{c}\text { Activity } \\
\text { Fraction }\end{array}$ & For $0.5 \mathrm{Ci}$ Total & $\begin{array}{l}\text { Relative } \\
\text { Density }\end{array}$ \\
\hline $13-1$ & & 640 & 12800 & $\mathrm{n}$ & & 12800 & $20.0 \%$ & & & $20.0 \%$ & 0.1000 & 1.00 \\
\hline $13-2$ & & 640 & 12800 & $\mathrm{n}$ & & 12800 & $20.0 \%$ & & & $20.0 \%$ & 0.1000 & 1.00 \\
\hline $13-3$ & & 640 & 12800 & $\mathrm{n}$ & & 12800 & $20.0 \%$ & & & $20.0 \%$ & 0.1000 & 1.00 \\
\hline $13-4$ & & 640 & 12800 & $\mathrm{n}$ & & 12800 & $20.0 \%$ & & & $20.0 \%$ & 0.1000 & 1.00 \\
\hline $13-5$ & & 640 & 12800 & $\mathrm{n}$ & & 12800 & $20.0 \%$ & & & $20.0 \%$ & 0.1000 & 1.00 \\
\hline Total & & & 64000 & & & 64000 & $100.0 \%$ & & & $100.0 \%$ & 0.5000 & \\
\hline
\end{tabular}




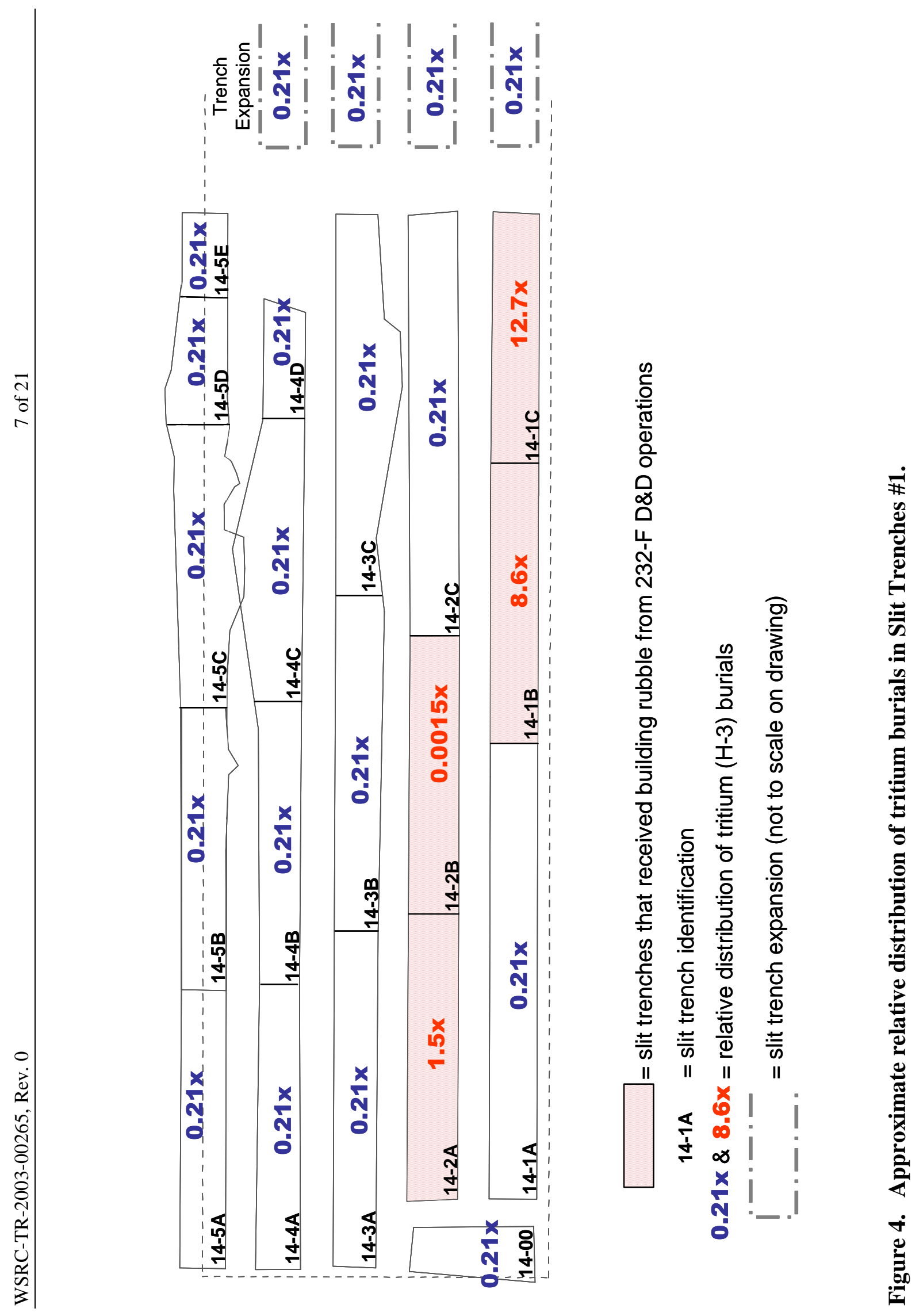




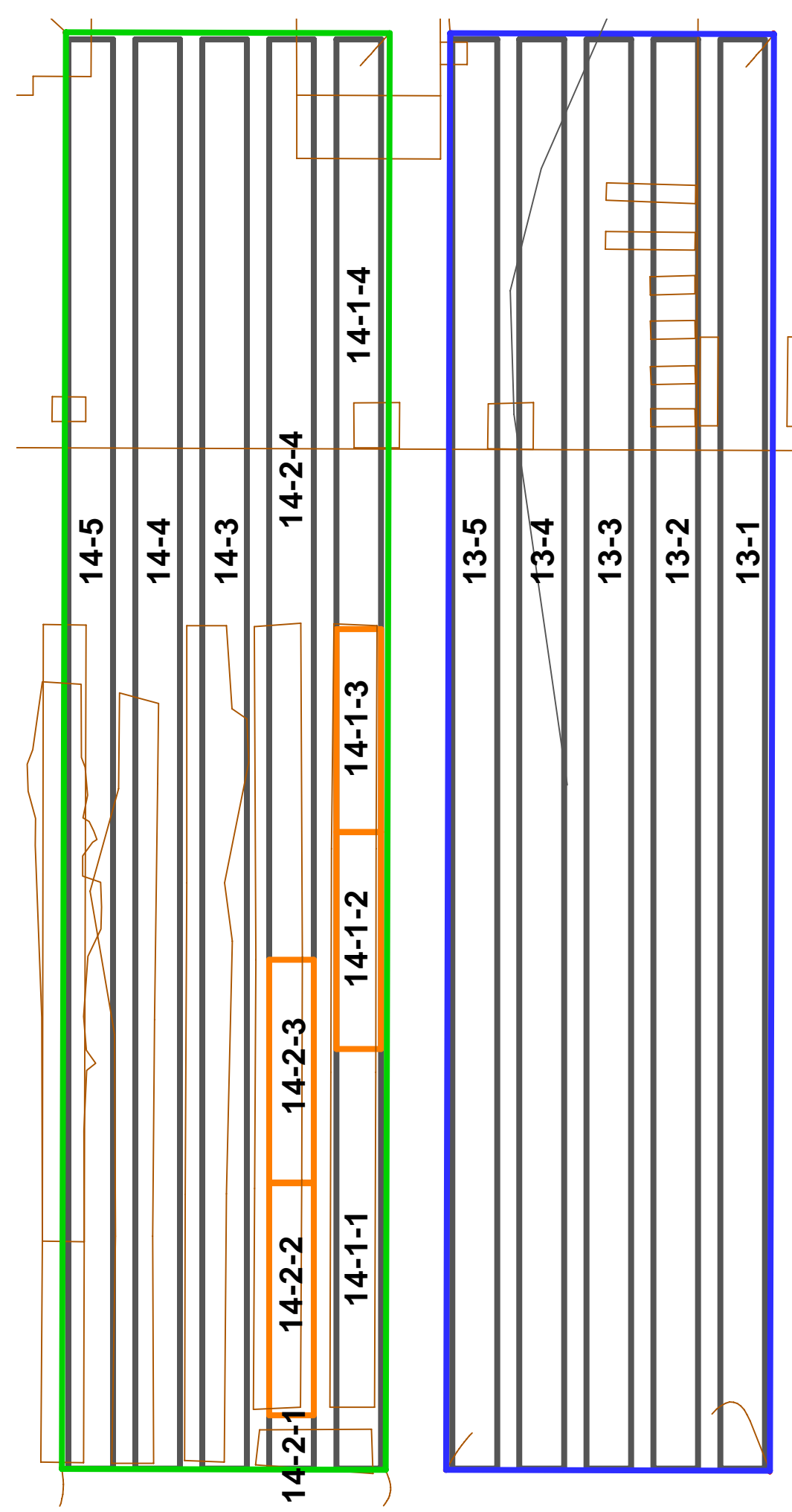

Figure 5. Slit Trenches \#1 and \#2 as represented in the PORFLOW aquifer model. 


\section{Leaching of Tritium to Soil Moisture}

In the PA, tritium is assumed to leach immediately from solid waste forms into soil moisture within the trench. That is, the entire inventory is assumed to be a solute at the start of a PORFLOW vadose zone transport simulation. Tritium migrates out of the waste zone by advection within a few years. For some waste forms (e.g tritium on shoe covers), this assumption may be a reasonable representation of reality. For other solid wastes, the assumption is clearly conservative.

Building 232-F rubble is comprised mainly of broken-up concrete with embedded tritium. For this waste form, tritium is expected to leach to backfilled trench soil slowly over time by diffusion and/or advective transport through low-permeability concrete. Hochel and Clark (2003) have estimated tritium release from the bottom of a typical slit trench. The conceptual model is that of decay-corrected plug-flow through a concrete monolith of trench cross-sectional dimensions, and stated to produce an "upper limit" or conservative estimate. The resulting fractional release rate $(\mathrm{Ci} / \mathrm{yr}$ release per $1 \mathrm{Ci}$ inventory) is shown in Figure 6. See Hochel and Clark (2003) for additional information.

\section{Hochel/Clark 15 Yr Decay-Corrected Plug-Flow Release}

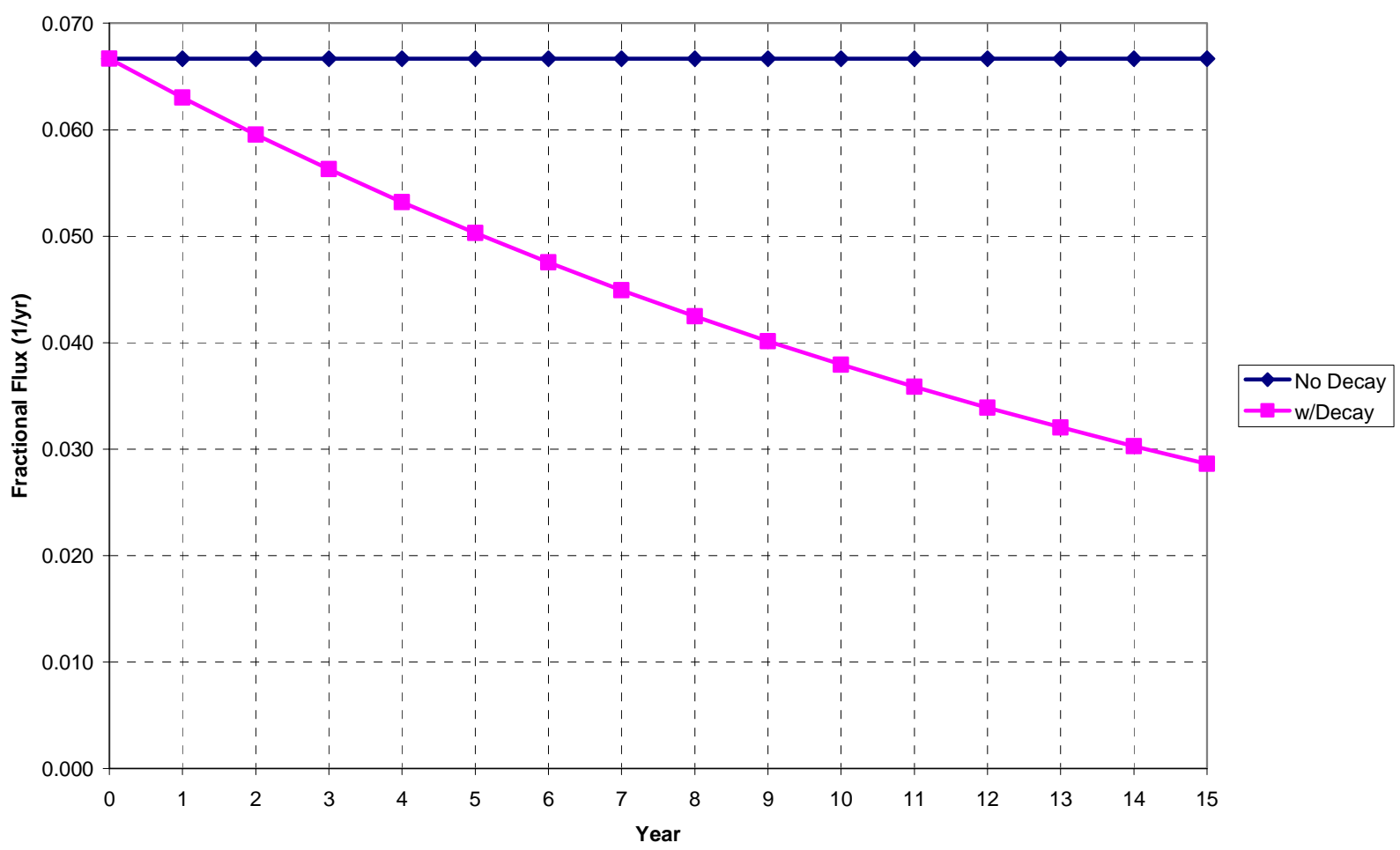

Figure 6. Fractional release of tritium from the bottom of a slit trench based on Hochel and Clark (2003). 


\section{PORFLOW Simulations}

If the groundwater pathway is limiting, peak aquifer concentration at a 100 meter well defines the Waste Acceptance Criteria (McDowell-Boyer et al. 2000). Peak aquifer concentrations are calculated in two phases. First transport through the vadose zone to the water table is simulated using a two-dimensional PORFLOW model representing a generic trench cross-section. The fractional flux from the vadose model, combined with a spatial distribution of waste in trenches, defines flux to the water table in the aquifer model. Specifically, the flux computed to be leaving the bottom of the vadose model at the water table is defined to be a mass flux source term in aquifer model nodes just beneath the water table underlying trenches. Groundwater recharge is specified at the ground surface in the aquifer model. Transport from the water table surface to a 100 meter well is simulated using a three-dimensional PORFLOW model. Collard (2002) describes how the vadose zone and aquifer models adopted for this study were developed. See the PORFLOW User's Manual for detailed information on the PORFLOW code (Analytical \& Computational Research Inc. 2000) and the PA (McDowell-Boyer et al. 2000) for additional information on modeling methods used.

Vadose zone water flow and H-3 transport were simulated for two mechanisms of tritium release from a slit trench. For the "Rapid (PA)" release mechanism, tritium is placed in the waste zone (trench) as a solute following the PA methodology. The entire inventory of tritium begins to migrate through the waste zone immediately. For the "Gradual (Hochel/Clark)" release, the flux shown in Figure 6 is placed at the bottom of the trench as an internal source. Fractional fluxes computed at the bottom of the trench and at the underlying water table are shown in Figure 7 for both release mechanisms. The Hochel/Clark release is observed to be more gradual, with a lower peak flux and longer duration.

For aquifer transport modeling, either fractional flux transient can be combined globally with either a "Uniform (PA)" or "As-Filled" inventory distribution. In addition, the Rapid (PA) and Gradual (Hochel/Clark) fractional fluxes can be used within the same simulation, by applying one to a portion of trenches and the other to the remaining area. In the "Uniform (PA)" scenario, waste is assumed to be uniformly distributed between and within Slit Trenches \#1 and \#2 following the PA methodology. In the "As-Filled" scenario, tritium is assumed to be uniformly distributed between Slit Trenches \#1 and \#2, and within Slit Trenches \#2. However, a nonuniform distribution resembling as-filled conditions is applied to Slit Trenches \#1. Table 3 defines the non-uniform as-filled distribution. The label "As-filled" is somewhat of a misnomer in that the distribution of tritium between Slit Trenches \#1 and \#2 (uniform or $0.5 \mathrm{Ci}$ each) is hypothetical. "As-filled" refers only to the distribution within the first set of 5 trenches.

Five aquifer transport scenarios were considered as summarized in Table 4. The first 4 simulations represent a single-effect parametric study of 2 distributions and 2 release models. In the fifth simulation, a combination of release models is applied. The Gradual (Hochel/Clark) fraction flux is applied only to the 232-F cementitious waste for which it was developed, and the remaining inventory in Slit Trenches \#1 and all of Slit Trenches \#2 is released using the default Rapid (PA) model. 
Peak aquifer concentrations for a $200 \mathrm{ft} \times 200 \mathrm{ft}$ window representing a 100 meter well at the resolution of the PA aquifer model (cf. Collard 2002) are given in Table 5 for the 5 scenarios considered in the present study. Also shown are the key results from related studies.

Table 4. Aquifer transport scenarios considered.

\begin{tabular}{|c|c|c|c|}
\hline Scenario & $\begin{array}{c}\text { Spatial Distribution for } \\
\text { Slit Trenches \#1 }\end{array}$ & $\begin{array}{c}\text { Release Model for } \\
\text { 232-F Burials }\end{array}$ & $\begin{array}{c}\text { Release Model for } \\
\text { Other Burials }\end{array}$ \\
\hline Simulation 1 & Uniform (PA) & Rapid (PA) & Rapid (PA) \\
\hline Simulation 2 & Uniform (PA) & Gradual (Hochel/Clark) & Gradual (Hochel/Clark) \\
\hline Simulation 3 & As-Filled & Rapid (PA) & Rapid (PA) \\
\hline Simulation 4 & As-Filled & Gradual (Hochel/Clark) & Gradual (Hochel/Clark) \\
\hline Simulation 5 & As-Filled & Gradual (Hochel/Clark) & Rapid (PA) \\
\hline
\end{tabular}

Table 5. Peak concentration results of aquifer transport simulation.

\section{Current study}

\begin{tabular}{cccclll}
\multicolumn{7}{c}{ Ratio to } \\
Simulation & H-3 pCi/L & Time (yrs) & PA & Spatial distribution & Release of 232-F & Release of Other \\
\hline 1 & 3199 & 11.8 & 2.01 & Uniform (PA) & Rapid (PA) & Rapid (PA) \\
2 & 1103 & 15.0 & 0.69 & Uniform (PA) & Gradual (Hochel/Clark) & Gradual (Hochel/Clark) \\
3 & 3380 & 12.3 & 2.13 & As-Filled & Rapid (PA) & Rapid (PA) \\
4 & 1085 & 15.0 & 0.68 & As-Filled & Gradual (Hochel/Clark) & Gradual (Hochel/Clark) \\
5 & 2189 & 12.5 & 1.38 & As-Filled & Gradual (Hochel/Clark) & Rapid (PA) \\
\hline
\end{tabular}

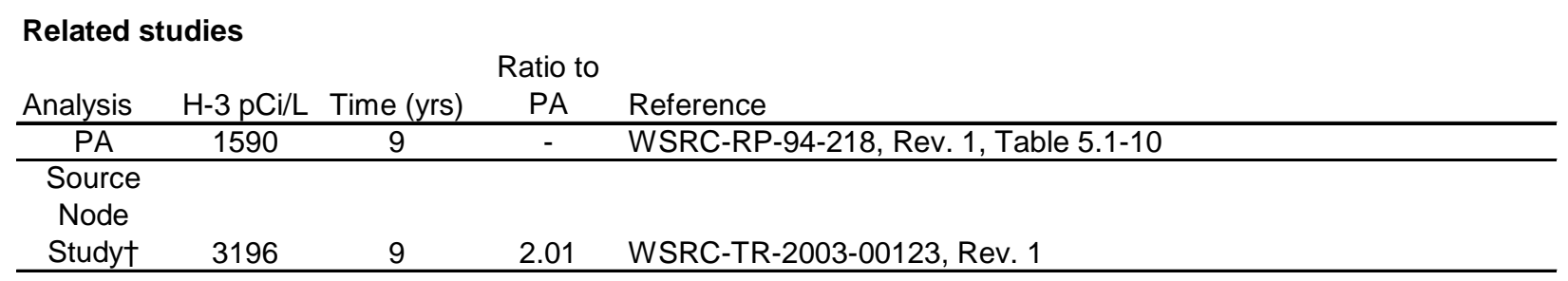




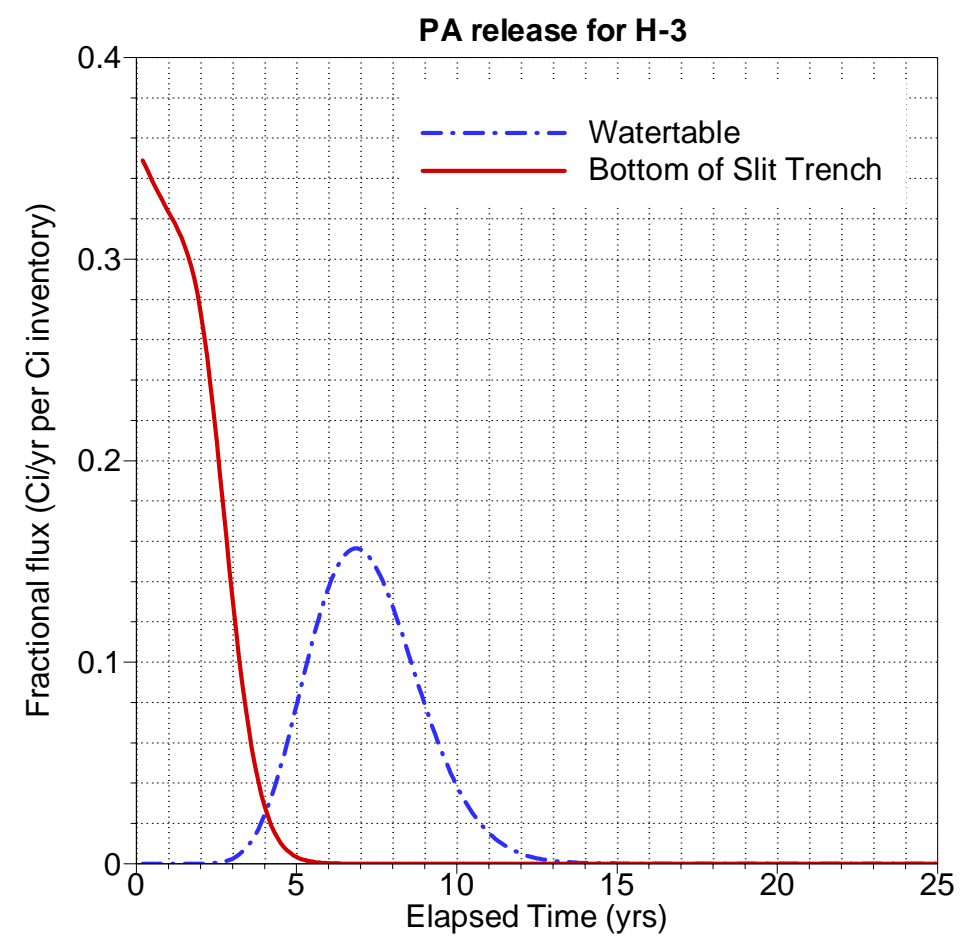

(a)

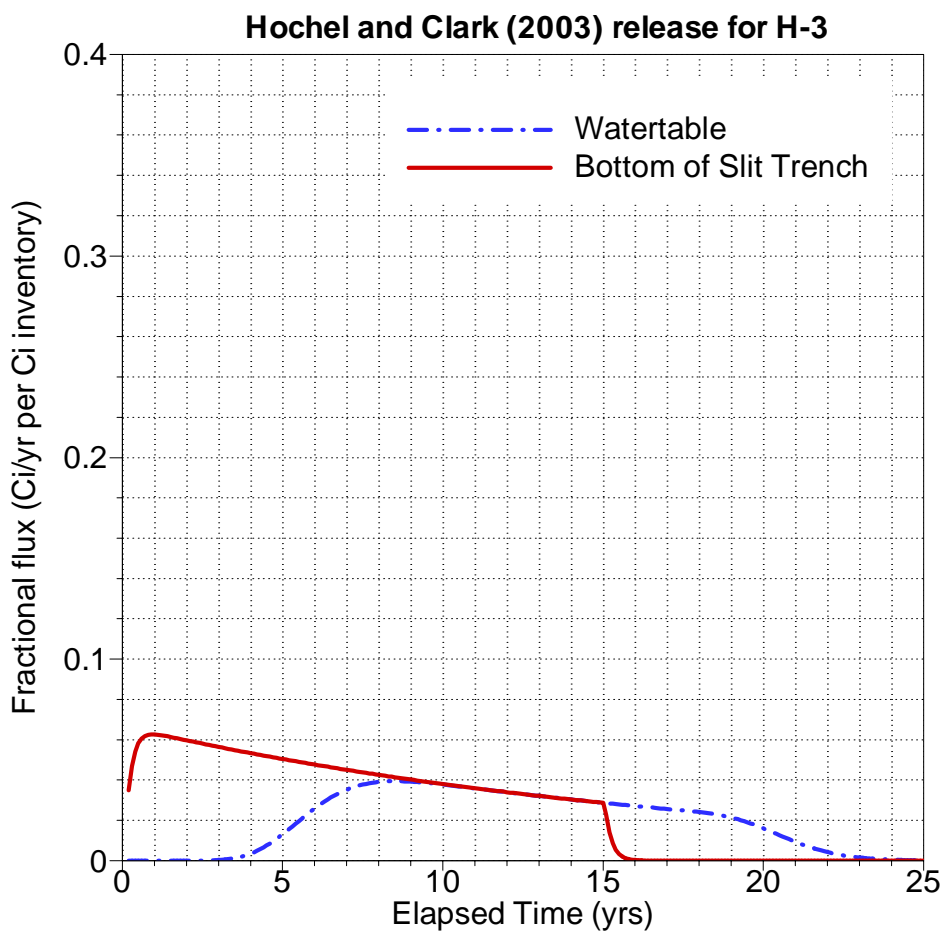

(b)

Figure 7. Fractional fluxes of tritium from the bottom of a slit trench and at the water table for: (a) Rapid (PA) release and (b) Hochel and Clark (2003) release. 


\section{Discussion of Results}

Simulation 1 resembles Case06 and Case07 for H-3 considered by Flach and Collard (2003) using the coarser-mesh aquifer transport model grid used in the PA. The latter cases involved a uniform distribution of waste over model footprints of the same area as the outline of Slit Trenches \#1 and \#2, and the "Rapid (PA)" release mode. Peak concentrations from the two studies are nearly the same as expected, but about twice as high as the PA value. Thus the present results are qualitatively the same as those of Collard (2002) for I-129 with respect to the PA. Collard (2002) and Flach and Collard (2003) discuss reasons for the difference with the PA.

Comparison of Simulations 1 and 3, and Simulations 2 and 4, indicates that the non-uniform, asfilled, distribution of tritium in Slit Trenches \#1 should not significantly impact peak aquifer concentration at a 100 meter well. However, the release model chosen has a large impact, on the order of $3 \times$, as can be seen by comparing Simulations 1 and 2 and Simulations 3 and 4. This effect is commensurate with the difference in fractional flux curves shown in Figure 7.

Simulation 5 assumes 232-F inventory is released relatively slowly per Hochel and Clark (2003), but all other tritium burials produce a rapid release to soil moisture and the water table. Compared to Simulation 1, which is conceptually equivalent to the PA methodology, the peak concentration is significantly lower (2189 versus $3199 \mathrm{pCi} / \mathrm{L})$. The Hochel and Clark (2003) model of tritium release is believed to be conservative (Hochel and Clark 2003, p. 4).

\section{Conclusions and Recommendations}

In Slit Trenches \#1, tritium comprised $85 \%$ of the sum-of-fractions through $4 / 16 / 03$, and $82 \%$ of the H-3 inventory is associated with $232-\mathrm{F}$ D\&D operations. Tritium activity from $232-\mathrm{F}$ is concentrated primarily in trench compartments 14-1B and 14-1C with a combined length of approximately $200 \mathrm{ft}$. In this area, the tritium density is roughly 10 times higher than the average. Although non-uniform, the as-filled distribution of tritium inventory in Slit Trenches \#1 is not expected to result in peak concentrations that are significantly higher than a uniform distribution, as assumed in the PA. This conclusion is specific to the particular distribution of tritium in Slit Trenches \#1.

Solid waste from 232-F is substantially in the form of concrete rubble. As discussed by Hochel and Clark (2003), tritium embedded within such concrete is expected to leach to trench soil moisture much more slowly than assumed in PA modeling. This study indicates the peak fractional flux to the water table would be approximately 4 times lower for tritium in cementitious wastes compared to instantaneous leaching. Corresponding peak H-3 groundwater concentrations are about 3 times lower for cementitious (e.g. 232-F) wastes. Consideration of waste form could offer an important opportunity to reduce conservatism in PA-based Waste Acceptance Criteria for tritium or other radionuclides. 


\section{References}

Analytical \& Computational Research, Inc. 2000. PORFLOW User's Manual, Version 4.00, April.

Collard, L.B. 2002. Effects of Point Sources in Slit Trenches at the E-Area Low-Level Waste Facility on Groundwater Concentrations, WSRC-TR-2002-00117, Rev. 0, Westinghouse Savannah River Company, Aiken, South Carolina, 29808, February.

Cook, J. R. 2002. Special Analysis: Correction and Update of E-Area Disposal Limits, WSRC-TR-2002-00047, Revision 2, Westinghouse Savannah River Company, Aiken, South Carolina, 29808, May.

Flach, G. P. and L. B. Collard. 2003. Evaluation of Aquifer Source Node Location Alternatives for E-Area Slit Trench Performance Assessment, WSRC-TR-2003-00123, Rev. 1, Westinghouse Savannah River Company, Aiken, South Carolina, 29808, May.

Hochel, R. C. and E. A. Clark. 2003. Estimated Release of Tritium from 232-F Concrete Rubble, WSRC-TR-2003-00264, Westinghouse Savannah River Company, Aiken, South Carolina, 29808, June.

McDowell-Boyer, L., A.D. Yu, J.R. Cook, D.C. Kocher, E.L. Wilhite, H. Holmes-Burns, and K.E. Young. 2000. Radiological Performance Assessment for the E-Area Low Level Waste Facility, WSRC-RP-94-218, Revision 1, Westinghouse Savannah River Company, Aiken, South Carolina, 29808, January.

Sink,D. 2003. E Area Vault Facilities Performance Assessment and Volumetric Status as of 4/16/03, OBU-SWE-2003-00058.

WSRC. 2002. WSRC IS Savannah River Site Waste Acceptance Criteria Manual, Procedure WAC 3.17 Low Level Radioactive Waste Acceptance Criteria, Rev. 7, September 16. 


\section{Appendix}

Facility operations information on 232-F D\&D building rubble burials provided by Shawn Reed:

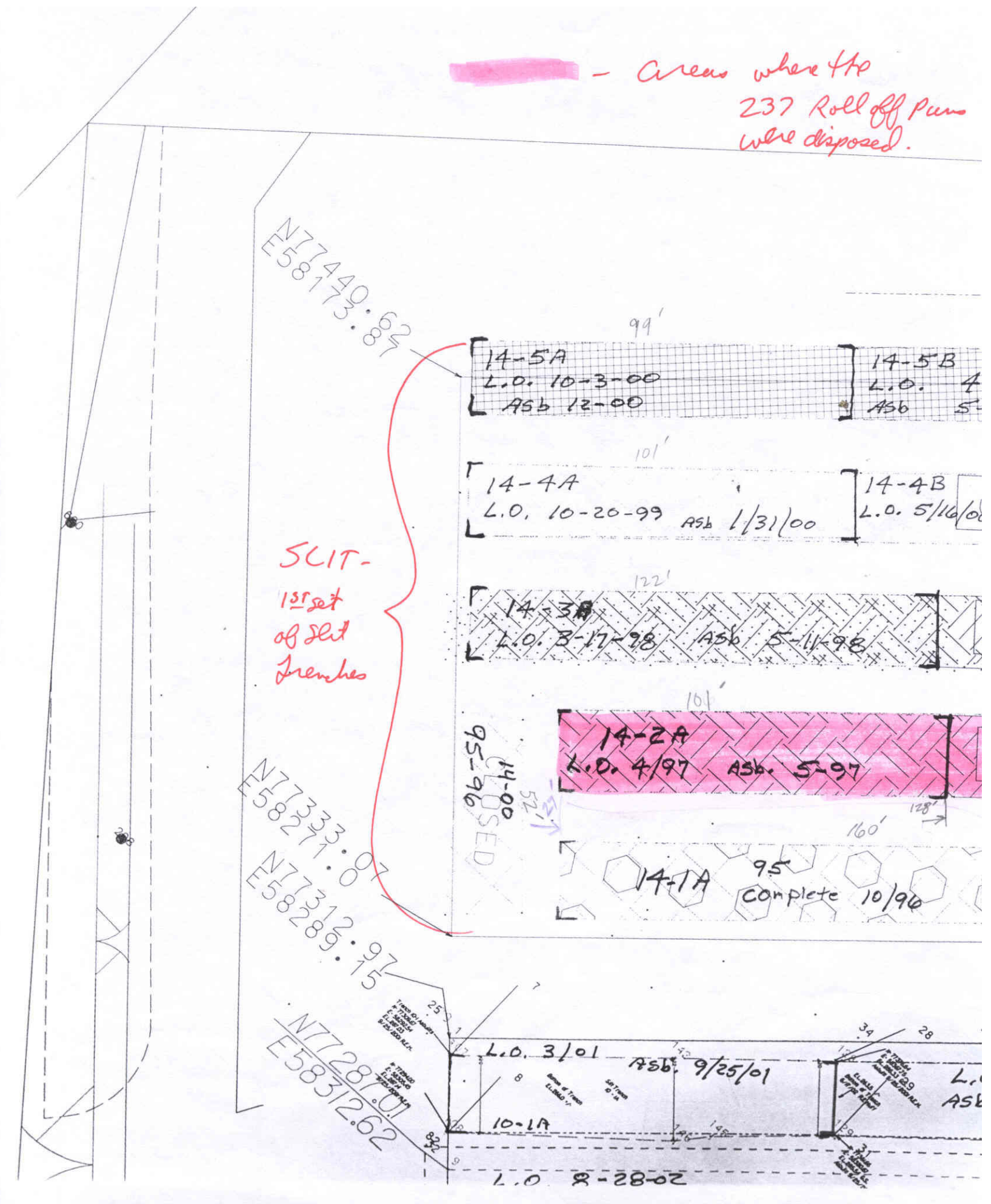




$$
\begin{aligned}
& \text { L.O = Layout? (Stant) } \\
& \text { Asb }=\text { Asbuit } \quad \text { (End) }
\end{aligned}
$$
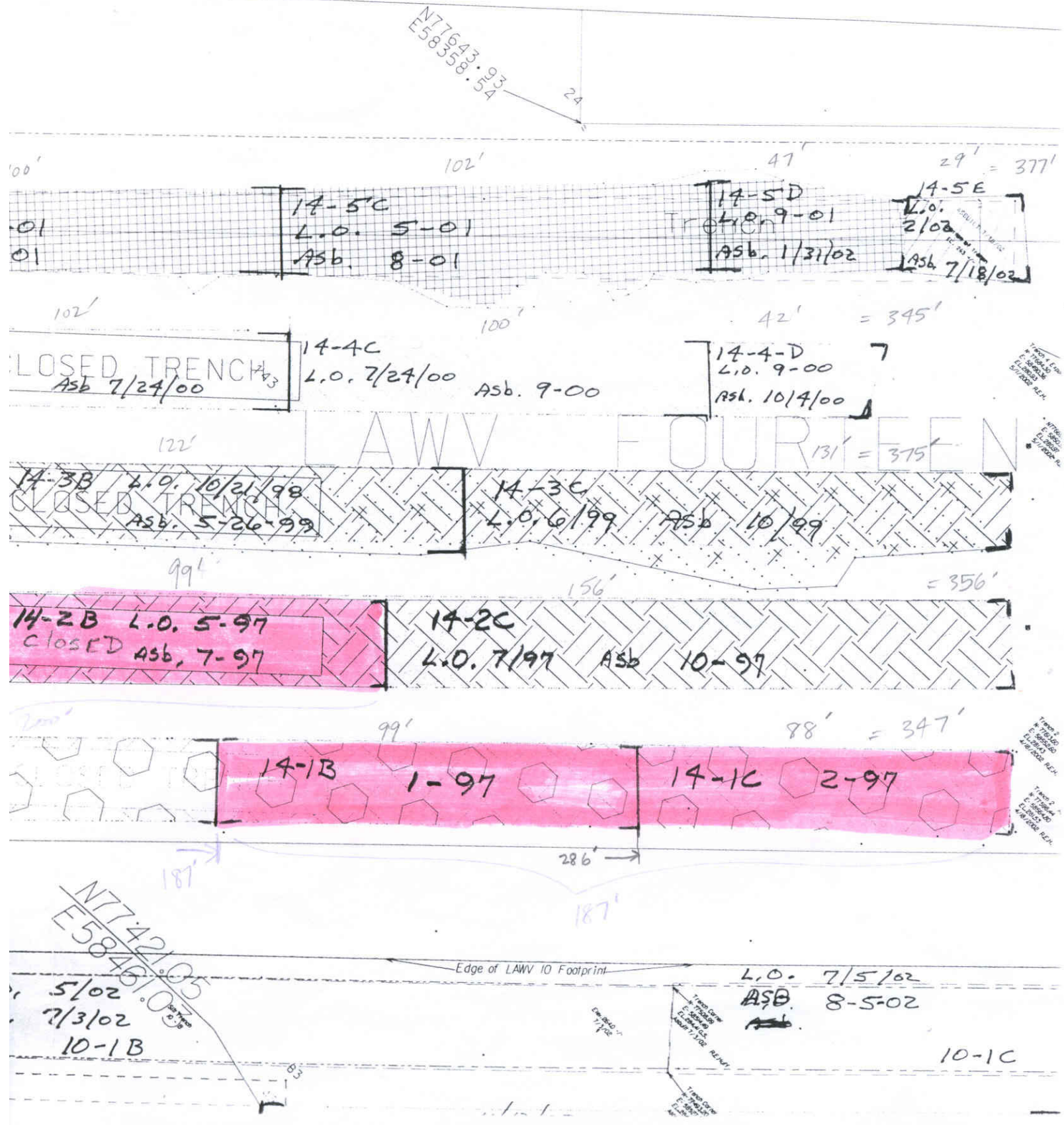
Waste Inventory Tracking System information on 232-F D\&D building rubble burials provided by Don Sink via e-mail dated 5/29/03:

\begin{tabular}{|c|c|c|c|c|c|c|c|}
\hline CNTNR_NUM & $\begin{array}{l}\text { Receipt } \\
\text { Date }\end{array}$ & Container Type & $\begin{array}{c}\text { Tare } \\
\text { Wt } \\
(\mathrm{kg})\end{array}$ & $\begin{array}{l}\text { Vol } \\
\text { (m3) }\end{array}$ & $\begin{array}{c}\text { Gross Wt } \\
(\mathrm{kg})\end{array}$ & $\begin{array}{l}\text { Activity } \\
\text { (ci) }\end{array}$ & $\begin{array}{c}\text { Waste Wt } \\
\quad(\mathrm{kg})\end{array}$ \\
\hline L0025 & 12/4/1996 & 19 CU YD ROLL OFF PAN & 2150.1 & 6.6838 & 25534 & 0.06 & 23384 \\
\hline L0026 & 12/5/1996 & 19 CU YD ROLL OFF PAN & 2150.1 & 6.6838 & 25534 & 0.06 & 23384 \\
\hline L0027 & 12/9/1996 & 19 CU YD ROLL OFF PAN & 2150.1 & 6.6838 & 25534 & 0.06 & 23384 \\
\hline L0028 & $12 / 13 / 1996$ & 19 CU YD ROLL OFF PAN & 2150.1 & 6.6838 & 25534 & 0.06 & 23384 \\
\hline L0029 & $12 / 16 / 1996$ & 19 CU YD ROLL OFF PAN & 2150.1 & 6.6838 & 25534 & 0.06 & 23384 \\
\hline L0030 & $12 / 26 / 1996$ & 19 CU YD ROLL OFF PAN & 2150.1 & 6.6838 & 25534 & 0.06 & 23384 \\
\hline L0031 & $1 / 6 / 1997$ & 19 CU YD ROLL OFF PAN & 2150.1 & 6.6838 & 25534 & 0.06 & 23384 \\
\hline L0032 & $12 / 16 / 1996$ & 19 CU YD ROLL OFF PAN & 2150.1 & 6.6838 & 25534 & 0.06 & 23384 \\
\hline L0033 & $1 / 13 / 1997$ & 19 CU YD ROLL OFF PAN & 2150.1 & 6.6838 & 25534 & 0.06 & 23384 \\
\hline L0034 & $1 / 14 / 1997$ & 19 CU YD ROLL OFF PAN & 2150.1 & 6.6838 & 25534 & 0.06 & 23384 \\
\hline L0035 & $1 / 14 / 1997$ & 19 CU YD ROLL OFF PAN & 2150.1 & 6.6838 & 25534 & 0.06 & 23384 \\
\hline L0036 & $1 / 14 / 1997$ & 19 CU YD ROLL OFF PAN & 2150.1 & 6.6838 & 25534 & 0.06 & 23384 \\
\hline L0037 & $1 / 14 / 1997$ & 19 CU YD ROLL OFF PAN & 2150.1 & 6.6838 & 25534 & 0.06 & 23384 \\
\hline L0038 & $1 / 15 / 1997$ & 19 CU YD ROLL OFF PAN & 2150.1 & 6.6838 & 25534 & 0.06 & 23384 \\
\hline L0039 & $1 / 15 / 1997$ & 19 CU YD ROLL OFF PAN & 2150.1 & 6.6838 & 25534 & 0.06 & 23384 \\
\hline L0040 & $1 / 15 / 1997$ & 19 CU YD ROLL OFF PAN & 2150.1 & 6.6838 & 25534 & 0.06 & 23384 \\
\hline L0041 & $1 / 17 / 1997$ & 19 CU YD ROLL OFF PAN & 2150.1 & 6.6838 & 25534 & 0.06 & 23384 \\
\hline L0042 & $1 / 17 / 1997$ & 19 CU YD ROLL OFF PAN & 2150.1 & 6.6838 & 25534 & 0.06 & 23384 \\
\hline L0043 & $1 / 17 / 1997$ & 19 CU YD ROLL OFF PAN & 2150.1 & 6.6838 & 25534 & 0.06 & 23384 \\
\hline L0044 & $1 / 28 / 1997$ & 19 CU YD ROLL OFF PAN & 2150.1 & 6.6838 & 25534 & 0.06 & 23384 \\
\hline L0045 & $1 / 28 / 1997$ & 19 CU YD ROLL OFF PAN & 2150.1 & 6.6838 & 25534 & 0.06 & 23384 \\
\hline L0047 & $1 / 28 / 1997$ & 19 CU YD ROLL OFF PAN & 2150.1 & 6.6838 & 25534 & 0.06 & 23384 \\
\hline L0048 & $1 / 28 / 1997$ & 19 CU YD ROLL OFF PAN & 2150.1 & 6.6838 & 25534 & 0.06 & 23384 \\
\hline L0049 & $1 / 29 / 1997$ & 19 CU YD ROLL OFF PAN & 2150.1 & 6.6838 & 25534 & 0.06 & 23384 \\
\hline L0050 & $1 / 29 / 1997$ & 19 CU YD ROLL OFF PAN & 2150.1 & 6.6838 & 25534 & 0.06 & 23384 \\
\hline L0051 & 2/3/1997 & 19 CU YD ROLL OFF PAN & 2150.1 & 6.6838 & 25534 & 0.06 & 23384 \\
\hline L0052 & 2/3/1997 & 19 CU YD ROLL OFF PAN & 2150.1 & 6.6838 & 25534 & 0.06 & 23384 \\
\hline L0053 & 2/3/1997 & 19 CU YD ROLL OFF PAN & 2150.1 & 6.6838 & 25534 & 0.06 & 23384 \\
\hline L0054 & 2/3/1997 & 19 CU YD ROLL OFF PAN & 2150.1 & 6.6838 & 25534 & 0.06 & 23384 \\
\hline L0055 & 2/3/1997 & 19 CU YD ROLL OFF PAN & 2150.1 & 6.6838 & 25534 & 0.06 & 23384 \\
\hline L0056 & 2/4/1997 & 19 CU YD ROLL OFF PAN & 2150.1 & 6.6838 & 25534 & 0.06 & 23384 \\
\hline L0057 & 2/4/1997 & 19 CU YD ROLL OFF PAN & 2150.1 & 6.6838 & 25534 & 0.06 & 23384 \\
\hline L0059 & 2/5/1997 & 19 CU YD ROLL OFF PAN & 2150.1 & 6.6838 & 25534 & 0.06 & 23384 \\
\hline L0060 & 2/5/1997 & 19 CU YD ROLL OFF PAN & 2150.1 & 6.6838 & 25534 & 0.06 & 23384 \\
\hline L0062 & 2/6/1997 & 19 CU YD ROLL OFF PAN & 2150.1 & 6.6838 & 25534 & 0.05 & 23384 \\
\hline L0063 & 2/6/1997 & 19 CU YD ROLL OFF PAN & 2150.1 & 6.6838 & 25534 & 0.05 & 23384 \\
\hline L0064 & 2/6/1997 & 19 CU YD ROLL OFF PAN & 2150.1 & 6.6838 & 25534 & 0.05 & 23384 \\
\hline L0065 & 2/6/1997 & 19 CU YD ROLL OFF PAN & 2150.1 & 6.6838 & 25534 & 0.05 & 23384 \\
\hline L0066 & 2/11/1997 & 19 CU YD ROLL OFF PAN & 2150.1 & 6.6838 & 25534 & 0.05 & 23384 \\
\hline L0067 & 2/11/1997 & 19 CU YD ROLL OFF PAN & 2150.1 & 6.6838 & 25534 & 0.05 & 23384 \\
\hline L0068 & 2/11/1997 & 19 CU YD ROLL OFF PAN & 2150.1 & 6.6838 & 25534 & 0.05 & 23384 \\
\hline L0069 & 2/11/1997 & 19 CU YD ROLL OFF PAN & 2150.1 & 6.6838 & 25534 & 0.05 & 23384 \\
\hline L0071 & 2/17/1997 & 19 CU YD ROLL OFF PAN & 2150.1 & 6.6838 & 25534 & 0.05 & 23384 \\
\hline L0072 & 2/17/1997 & 19 CU YD ROLL OFF PAN & 2150.1 & 6.6838 & 25534 & 0.05 & 23384 \\
\hline
\end{tabular}




\begin{tabular}{|c|c|c|c|c|c|c|c|}
\hline L0073 & $2 / 17 / 1997$ & 19 CU YD ROLL OFF PAN & 2150.1 & 6.6838 & 25534 & 0.05 & 23384 \\
\hline L0074 & $2 / 17 / 1997$ & 19 CU YD ROLL OFF PAN & 2150.1 & 6.6838 & 25534 & 0.05 & 23384 \\
\hline L0075 & 2/17/1997 & 19 CU YD ROLL OFF PAN & 2150.1 & 6.6838 & 25534 & 0.05 & 23384 \\
\hline L0076 & 2/18/1997 & 19 CU YD ROLL OFF PAN & 2150.1 & 6.6838 & 25534 & 0.05 & 23384 \\
\hline L0077 & $2 / 18 / 1997$ & 19 CU YD ROLL OFF PAN & 2150.1 & 6.6838 & 25534 & 0.05 & 23384 \\
\hline L0078 & $2 / 18 / 1997$ & 19 CU YD ROLL OFF PAN & 2150.1 & 6.6838 & 25534 & 0.05 & 23384 \\
\hline L0079 & 2/18/1997 & 19 CU YD ROLL OFF PAN & 2150.1 & 6.6838 & 25534 & 0.05 & 23384 \\
\hline L0080 & $2 / 18 / 1997$ & 19 CU YD ROLL OFF PAN & 2150.1 & 6.6838 & 25534 & 0.05 & 23384 \\
\hline L0081 & $2 / 19 / 1997$ & 19 CU YD ROLL OFF PAN & 2150.1 & 6.6838 & 25534 & 0.01 & 23384 \\
\hline L0082 & 2/19/1997 & 19 CU YD ROLL OFF PAN & 2150.1 & 6.6838 & 25534 & 0.01 & 23384 \\
\hline L0083 & 2/19/1997 & 19 CU YD ROLL OFF PAN & 2150.1 & 6.6838 & 25534 & 0.01 & 23384 \\
\hline L0084 & 2/19/1997 & 19 CU YD ROLL OFF PAN & 2150.1 & 6.6838 & 25534 & 0.01 & 23384 \\
\hline L0085 & 2/19/1997 & 19 CU YD ROLL OFF PAN & 2150.1 & 6.6838 & 25534 & 0.01 & 23384 \\
\hline L0086 & 2/20/1997 & 19 CU YD ROLL OFF PAN & 2150.1 & 6.6838 & 25534 & 0.01 & 23384 \\
\hline L0087 & 2/20/1997 & 19 CU YD ROLL OFF PAN & 2150.1 & 6.6838 & 25534 & 0.01 & 23384 \\
\hline L0088 & 2/20/1997 & 19 CU YD ROLL OFF PAN & 2150.1 & 6.6838 & 25534 & 0.01 & 23384 \\
\hline L0089 & 2/20/1997 & 19 CU YD ROLL OFF PAN & 2150.1 & 6.6838 & 25534 & 0.01 & 23384 \\
\hline L0090 & 2/20/1997 & 19 CU YD ROLL OFF PAN & 2150.1 & 6.6838 & 25534 & 0.01 & 23384 \\
\hline L0091 & $2 / 24 / 1997$ & 19 CU YD ROLL OFF PAN & 2150.1 & 6.6838 & 25534 & 0.01 & 23384 \\
\hline L0092 & 2/24/1997 & 19 CU YD ROLL OFF PAN & 2150.1 & 6.6838 & 25534 & 0.01 & 23384 \\
\hline L0093 & $2 / 24 / 1997$ & 19 CU YD ROLL OFF PAN & 2150.1 & 6.6838 & 25534 & 0.01 & 23384 \\
\hline L0094 & 2/24/1997 & 19 CU YD ROLL OFF PAN & 2150.1 & 6.6838 & 25534 & 0.01 & 23384 \\
\hline L0095 & 2/24/1997 & 19 CU YD ROLL OFF PAN & 2150.1 & 6.6838 & 25534 & 0.01 & 23384 \\
\hline L0096 & 2/26/1997 & 19 CU YD ROLL OFF PAN & 2150.1 & 6.6838 & 25534 & 0.01 & 23384 \\
\hline L0097 & 2/26/1997 & 19 CU YD ROLL OFF PAN & 2150.1 & 6.6838 & 25534 & 0.01 & 23384 \\
\hline L0099 & 2/26/1997 & 19 CU YD ROLL OFF PAN & 2150.1 & 6.6838 & 25534 & 0.01 & 23384 \\
\hline L0100 & 2/27/1997 & 19 CU YD ROLL OFF PAN & 2150.1 & 6.6838 & 25534 & 0.01 & 23384 \\
\hline L0101 & 2/27/1997 & 19 CU YD ROLL OFF PAN & 2150.1 & 6.6838 & 25534 & 0.005 & 23384 \\
\hline L0102 & 2/27/1997 & 19 CU YD ROLL OFF PAN & 2150.1 & 6.6838 & 25534 & 0.005 & 23384 \\
\hline L0103 & 2/27/1997 & 19 CU YD ROLL OFF PAN & 2150.1 & 6.6838 & 25534 & 0.005 & 23384 \\
\hline L0104 & 2/27/1997 & 19 CU YD ROLL OFF PAN & 2150.1 & 6.6838 & 25534 & 0.005 & 23384 \\
\hline L0105 & $2 / 27 / 1997$ & 19 CU YD ROLL OFF PAN & 2150.1 & 6.6838 & 25534 & 0.005 & 23384 \\
\hline L0106 & 3/5/1997 & 19 CU YD ROLL OFF PAN & 2150.1 & 6.6838 & 25534 & 0.005 & 23384 \\
\hline L0108 & 3/5/1997 & 19 CU YD ROLL OFF PAN & 2150.1 & 6.6838 & 25534 & 0.005 & 23384 \\
\hline L0109 & $3 / 5 / 1997$ & 19 CU YD ROLL OFF PAN & 2150.1 & 6.6838 & 25534 & 0.005 & 23384 \\
\hline L0111 & 3/5/1997 & 19 CU YD ROLL OFF PAN & 2150.1 & 6.6838 & 25534 & 0.005 & 23384 \\
\hline L0112 & 3/10/1997 & 19 CU YD ROLL OFF PAN & 2150.1 & 6.6838 & 25534 & 0.005 & 23384 \\
\hline L0113 & 3/10/1997 & 19 CU YD ROLL OFF PAN & 2150.1 & 6.6838 & 25534 & 0.005 & 23384 \\
\hline L0114 & 3/10/1997 & 19 CU YD ROLL OFF PAN & 2150.1 & 6.6838 & 25534 & 0.005 & 23384 \\
\hline L0115 & 3/10/1997 & 19 CU YD ROLL OFF PAN & 2150.1 & 6.6838 & 25534 & 0.005 & 23384 \\
\hline L0116 & 3/10/1997 & 19 CU YD ROLL OFF PAN & 2150.1 & 6.6838 & 25534 & 0.005 & 23384 \\
\hline L0117 & 3/10/1997 & 19 CU YD ROLL OFF PAN & 2150.1 & 6.6838 & 25534 & 0.005 & 23384 \\
\hline L0118 & $3 / 11 / 1997$ & 19 CU YD ROLL OFF PAN & 2150.1 & 6.6838 & 25534 & 0.005 & 23384 \\
\hline L0119 & $3 / 11 / 1997$ & 19 CU YD ROLL OFF PAN & 2150.1 & 6.6838 & 25534 & 0.005 & 23384 \\
\hline L0120 & $3 / 11 / 1997$ & 19 CU YD ROLL OFF PAN & 2150.1 & 6.6838 & 25534 & 0.005 & 23384 \\
\hline L0121 & $3 / 11 / 1997$ & 19 CU YD ROLL OFF PAN & 2150.1 & 6.6838 & 25534 & 0.005 & 23384 \\
\hline L0122 & $3 / 11 / 1997$ & 19 CU YD ROLL OFF PAN & 2150.1 & 6.6838 & 25534 & 0.005 & 23384 \\
\hline L0124 & $3 / 11 / 1997$ & 19 CU YD ROLL OFF PAN & 2150.1 & 6.6838 & 25534 & 0.005 & 23384 \\
\hline L0125 & $3 / 11 / 1997$ & 19 CU YD ROLL OFF PAN & 2150.1 & 6.6838 & 25534 & 0.005 & 23384 \\
\hline
\end{tabular}




\begin{tabular}{|c|c|c|c|c|c|c|c|}
\hline L0126 & 3/11/1997 & 19 CU YD ROLL OFF PAN & 2150.1 & 6.6838 & 25534 & 0.005 & 23384 \\
\hline L0127 & 3/11/1997 & 19 CU YD ROLL OFF PAN & 2150.1 & 6.6838 & 25534 & 0.005 & 23384 \\
\hline L0128 & 3/12/1997 & 19 CU YD ROLL OFF PAN & 2150.1 & 6.6838 & 25534 & 0.005 & 23384 \\
\hline L0129 & 3/12/1997 & 19 CU YD ROLL OFF PAN & 2150.1 & 6.6838 & 25534 & 0.005 & 23384 \\
\hline L0130 & 3/12/1997 & 19 CU YD ROLL OFF PAN & 2150.1 & 6.6838 & 25534 & 0.005 & 23384 \\
\hline L0131 & 3/12/1997 & 19 CU YD ROLL OFF PAN & 2150.1 & 6.6838 & 25534 & 0.005 & 23384 \\
\hline L0132 & 3/12/1997 & 19 CU YD ROLL OFF PAN & 2150.1 & 6.6838 & 25534 & 0.005 & 23384 \\
\hline L0133 & 3/12/1997 & 19 CU YD ROLL OFF PAN & 2150.1 & 6.6838 & 25534 & 0.005 & 23384 \\
\hline L0134 & 3/12/1997 & 19 CU YD ROLL OFF PAN & 2150.1 & 6.6838 & 25534 & 0.005 & 23384 \\
\hline L0135 & 3/17/1997 & 19 CU YD ROLL OFF PAN & 2150.1 & 6.6838 & 25534 & 0.005 & 23384 \\
\hline L0136 & 3/17/1997 & 19 CU YD ROLL OFF PAN & 2150.1 & 6.6838 & 25534 & 0.005 & 23384 \\
\hline L0137 & 3/17/1997 & 19 CU YD ROLL OFF PAN & 2150.1 & 6.6838 & 25534 & 0.005 & 23384 \\
\hline L0138 & 3/17/1997 & 19 CU YD ROLL OFF PAN & 2150.1 & 6.6838 & 25534 & 0.005 & 23384 \\
\hline L0139 & 3/18/1997 & 19 CU YD ROLL OFF PAN & 2150.1 & 6.6838 & 25534 & 0.005 & 23384 \\
\hline L0140 & 3/18/1997 & 19 CU YD ROLL OFF PAN & 2150.1 & 6.6838 & 25534 & 0.005 & 23384 \\
\hline L0141 & 3/18/1997 & 19 CU YD ROLL OFF PAN & 2150.1 & 6.6838 & 25534 & 0.002 & 23384 \\
\hline L0142 & 3/18/1997 & 19 CU YD ROLL OFF PAN & 2150.1 & 6.6838 & 25534 & 0.002 & 23384 \\
\hline L0143 & 3/18/1997 & 19 CU YD ROLL OFF PAN & 2150.1 & 6.6838 & 25534 & 0.002 & 23384 \\
\hline L0144 & 3/18/1997 & 19 CU YD ROLL OFF PAN & 2150.1 & 6.6838 & 25534 & 0.002 & 23384 \\
\hline L0145 & 3/19/1997 & 19 CU YD ROLL OFF PAN & 2150.1 & 6.6838 & 25534 & 0.002 & 23384 \\
\hline L0146 & 3/19/1997 & 19 CU YD ROLL OFF PAN & 2150.1 & 6.6838 & 25534 & 0.002 & 23384 \\
\hline L0147 & 3/19/1997 & 19 CU YD ROLL OFF PAN & 2150.1 & 6.6838 & 25534 & 0.002 & 23384 \\
\hline L0148 & 3/19/1997 & 19 CU YD ROLL OFF PAN & 2150.1 & 6.6838 & 25534 & 0.002 & 23384 \\
\hline L0149 & 3/20/1997 & 19 CU YD ROLL OFF PAN & 2150.1 & 6.6838 & 25534 & 0.002 & 23384 \\
\hline L0150 & 3/20/1997 & 19 CU YD ROLL OFF PAN & 2150.1 & 6.6838 & 25534 & 0.002 & 23384 \\
\hline L0151 & 3/20/1997 & 19 CU YD ROLL OFF PAN & 2150.1 & 6.6838 & 25534 & 0.002 & 23384 \\
\hline L0152 & 3/20/1997 & 19 CU YD ROLL OFF PAN & 2150.1 & 6.6838 & 25534 & 0.002 & 23384 \\
\hline L0154 & 3/20/1997 & 19 CU YD ROLL OFF PAN & 2150.1 & 6.6838 & 25534 & 0.002 & 23384 \\
\hline L0155 & 3/25/1997 & 19 CU YD ROLL OFF PAN & 2150.1 & 6.6838 & 25534 & 0.002 & 23384 \\
\hline L0156 & $3 / 25 / 1997$ & 19 CU YD ROLL OFF PAN & 2150.1 & 6.6838 & 25534 & 0.002 & 23384 \\
\hline L0157 & $3 / 25 / 1997$ & 19 CU YD ROLL OFF PAN & 2150.1 & 6.6838 & 25534 & 0.002 & 23384 \\
\hline L0158 & 3/25/1997 & 19 CU YD ROLL OFF PAN & 2150.1 & 6.6838 & 25534 & 0.002 & 23384 \\
\hline L0159 & $3 / 25 / 1997$ & 19 CU YD ROLL OFF PAN & 2150.1 & 6.6838 & 25534 & 0.002 & 23384 \\
\hline L0160 & $3 / 25 / 1997$ & 19 CU YD ROLL OFF PAN & 2150.1 & 6.6838 & 25534 & 0.002 & 23384 \\
\hline L0161 & $3 / 26 / 1997$ & 19 CU YD ROLL OFF PAN & 2150.1 & 6.6838 & 25534 & 0.002 & 23384 \\
\hline L0162 & 3/26/1997 & 19 CU YD ROLL OFF PAN & 2150.1 & 6.6838 & 25534 & 0.002 & 23384 \\
\hline L0163 & $3 / 26 / 1997$ & 19 CU YD ROLL OFF PAN & 2150.1 & 6.6838 & 25534 & 0.002 & 23384 \\
\hline L0164 & 3/26/1997 & 19 CU YD ROLL OFF PAN & 2150.1 & 6.6838 & 25534 & 0.002 & 23384 \\
\hline L0165 & $3 / 26 / 1997$ & 19 CU YD ROLL OFF PAN & 2150.1 & 6.6838 & 25534 & 0.002 & 23384 \\
\hline L0166 & 3/26/1997 & 19 CU YD ROLL OFF PAN & 2150.1 & 6.6838 & 25534 & 0.002 & 23384 \\
\hline L0168 & 4/1/1997 & 19 CU YD ROLL OFF PAN & 2150.1 & 6.6838 & 25534 & 0.002 & 23384 \\
\hline L0169 & $4 / 1 / 1997$ & 19 CU YD ROLL OFF PAN & 2150.1 & 6.6838 & 25534 & 0.002 & 23384 \\
\hline L0170 & 4/1/1997 & 19 CU YD ROLL OFF PAN & 2150.1 & 6.6838 & 25534 & 0.002 & 23384 \\
\hline L0171 & $4 / 1 / 1997$ & 19 CU YD ROLL OFF PAN & 2150.1 & 6.6838 & 25534 & 0.002 & 23384 \\
\hline L0172 & $4 / 1 / 1997$ & 19 CU YD ROLL OFF PAN & 2150.1 & 6.6838 & 25534 & 0.002 & 23384 \\
\hline L0173 & 4/2/1997 & 19 CU YD ROLL OFF PAN & 2150.1 & 6.6838 & 25534 & 0.002 & 23384 \\
\hline L0174 & $4 / 2 / 1997$ & 19 CU YD ROLL OFF PAN & 2150.1 & 6.6838 & 25534 & 0.002 & 23384 \\
\hline L0175 & 4/2/1997 & 19 CU YD ROLL OFF PAN & 2150.1 & 6.6838 & 25534 & 0.002 & 23384 \\
\hline L0177 & 4/2/1997 & 19 CU YD ROLL OFF PAN & 2150.1 & 6.6838 & 25534 & 0.002 & 23384 \\
\hline
\end{tabular}




\begin{tabular}{|c|c|c|c|c|c|c|c|}
\hline L0178 & 4/2/1997 & 19 CU YD ROLL OFF PAN & 2150.1 & 6.6838 & 25534 & 0.002 & 23384 \\
\hline L0179 & $4 / 15 / 1997$ & 19 CU YD ROLL OFF PAN & 2150.1 & 6.6838 & 25534 & 0.002 & 23384 \\
\hline L0180 & 4/15/1997 & 19 CU YD ROLL OFF PAN & 2150.1 & 6.6838 & 25534 & 0.002 & 23384 \\
\hline L0181 & $4 / 15 / 1997$ & 19 CU YD ROLL OFF PAN & 2150.1 & 6.6838 & 25534 & 0.002 & 23384 \\
\hline L0182 & $4 / 15 / 1997$ & 19 CU YD ROLL OFF PAN & 2150.1 & 6.6838 & 25534 & 0.002 & 23384 \\
\hline L0183 & $4 / 15 / 1997$ & 19 CU YD ROLL OFF PAN & 2150.1 & 6.6838 & 25534 & 0.002 & 23384 \\
\hline L0184 & 4/15/1997 & 19 CU YD ROLL OFF PAN & 2150.1 & 6.6838 & 25534 & 0.002 & 23384 \\
\hline L0185 & $4 / 17 / 1997$ & 19 CU YD ROLL OFF PAN & 2150.1 & 6.6838 & 25534 & 0.002 & 23384 \\
\hline L0186 & $4 / 17 / 1997$ & 19 CU YD ROLL OFF PAN & 2150.1 & 6.6838 & 25534 & 0.002 & 23384 \\
\hline L0187 & $4 / 17 / 1997$ & 19 CU YD ROLL OFF PAN & 2150.1 & 6.6838 & 25534 & 0.002 & 23384 \\
\hline L0188 & $4 / 17 / 1997$ & 19 CU YD ROLL OFF PAN & 2150.1 & 6.6838 & 25534 & 0.002 & 23384 \\
\hline L0189 & $4 / 17 / 1997$ & 19 CU YD ROLL OFF PAN & 2150.1 & 6.6838 & 25534 & 0.002 & 23384 \\
\hline L0191 & $5 / 6 / 1997$ & 19 CU YD ROLL OFF PAN & 2150.1 & 6.6838 & 25534 & 0.01 & 23384 \\
\hline L0192 & $5 / 6 / 1997$ & 19 CU YD ROLL OFF PAN & 2150.1 & 6.6838 & 25534 & 0.002 & 23384 \\
\hline L0193 & $5 / 6 / 1997$ & 19 CU YD ROLL OFF PAN & 2150.1 & 6.6838 & 25534 & 0.002 & 23384 \\
\hline L0194 & $5 / 6 / 1997$ & 19 CU YD ROLL OFF PAN & 2150.1 & 6.6838 & 25534 & 0.002 & 23384 \\
\hline L0195 & $5 / 6 / 1997$ & 19 CU YD ROLL OFF PAN & 2150.1 & 6.6838 & 25534 & 0.002 & 23384 \\
\hline L0196 & $5 / 6 / 1997$ & 19 CU YD ROLL OFF PAN & 2150.1 & 6.6838 & 25534 & 0.002 & 23384 \\
\hline L0197 & $5 / 12 / 1997$ & 19 CU YD ROLL OFF PAN & 2150.1 & 6.6838 & 25534 & 0.002 & 23384 \\
\hline L0199 & $5 / 12 / 1997$ & 19 CU YD ROLL OFF PAN & 2150.1 & 6.6838 & 25534 & 0.002 & 23384 \\
\hline L0200 & $5 / 12 / 1997$ & 19 CU YD ROLL OFF PAN & 2150.1 & 6.6838 & 25534 & 0.002 & 23384 \\
\hline L0205 & $5 / 14 / 1997$ & 19 CU YD ROLL OFF PAN & 2150.1 & 6.6838 & 25534 & 0.04 & 23384 \\
\hline L0201 & $5 / 12 / 1997$ & 19 CU YD ROLL OFF PAN & 2150.1 & 6.6838 & 25534 & 0.002 & 23384 \\
\hline L0202 & $5 / 12 / 1997$ & 19 CU YD ROLL OFF PAN & 2150.1 & 6.6838 & 25534 & 0.002 & 23384 \\
\hline L0203 & $5 / 13 / 1997$ & 19 CU YD ROLL OFF PAN & 2150.1 & 6.6838 & 25520 & 0.002 & 23370 \\
\hline L0204 & $5 / 13 / 1997$ & 19 CU YD ROLL OFF PAN & 2150.1 & 6.6838 & 25534 & 0.002 & 23384 \\
\hline L0206 & $5 / 14 / 1997$ & 19 CU YD ROLL OFF PAN & 2150.1 & 6.6838 & 25534 & 0.04 & 23384 \\
\hline L0207 & $5 / 15 / 1997$ & 19 CU YD ROLL OFF PAN & 2150.1 & 6.6838 & 25987 & 0.04 & 23837 \\
\hline L0208 & $5 / 14 / 1997$ & 19 CU YD ROLL OFF PAN & 2150.1 & 6.6838 & 25987 & 0.04 & 23837 \\
\hline L0209 & $5 / 14 / 1997$ & 19 CU YD ROLL OFF PAN & 2150.1 & 6.6838 & 25987 & 0.04 & 23837 \\
\hline L0211 & $5 / 15 / 1997$ & 19 CU YD ROLL OFF PAN & 2150.1 & 6.6838 & 25534 & 0.00001 & 23384 \\
\hline L0212 & $5 / 15 / 1997$ & 19 CU YD ROLL OFF PAN & 2150.1 & 6.6838 & 25534 & 0.00001 & 23384 \\
\hline L0213 & $5 / 15 / 1997$ & 19 CU YD ROLL OFF PAN & 2150.1 & 6.6838 & 25534 & 0.00001 & 23384 \\
\hline L0214 & $5 / 15 / 1997$ & 19 CU YD ROLL OFF PAN & 2150.1 & 6.6838 & 25534 & 0.00001 & 23384 \\
\hline L0215 & $5 / 15 / 1997$ & 19 CU YD ROLL OFF PAN & 2150.1 & 6.6838 & 25520 & 0.00001 & 23370 \\
\hline L0216 & $5 / 15 / 1997$ & 19 CU YD ROLL OFF PAN & 2150.1 & 6.6838 & 25534 & 0.00001 & 23384 \\
\hline L0217 & $5 / 20 / 1997$ & 19 CU YD ROLL OFF PAN & 2150.1 & 6.6838 & 25534 & 0.00001 & 23384 \\
\hline L0218 & $5 / 20 / 1997$ & 19 CU YD ROLL OFF PAN & 2150.1 & 6.6838 & 25534 & 0.00001 & 23384 \\
\hline L0219 & $5 / 20 / 1997$ & 19 CU YD ROLL OFF PAN & 2150.1 & 6.6838 & 25534 & 0.00001 & 23384 \\
\hline L0220 & $5 / 20 / 1997$ & 19 CU YD ROLL OFF PAN & 2150.1 & 6.6838 & 25534 & 0.00001 & 23384 \\
\hline L0221 & $5 / 20 / 1997$ & 19 CU YD ROLL OFF PAN & 2150.1 & 6.6838 & 25534 & 0.00001 & 23384 \\
\hline L0222 & $5 / 20 / 1997$ & 19 CU YD ROLL OFF PAN & 2150.1 & 6.6838 & 25534 & 0.00001 & 23384 \\
\hline L0223 & $5 / 22 / 1997$ & 19 CU YD ROLL OFF PAN & 2150.1 & 6.6838 & 25534 & 0.00001 & 23384 \\
\hline L0224 & $5 / 22 / 1997$ & 19 CU YD ROLL OFF PAN & 2150.1 & 6.6838 & 25534 & 0.00001 & 23384 \\
\hline L0225 & $5 / 22 / 1997$ & 19 CU YD ROLL OFF PAN & 2150.1 & 6.6838 & 25534 & 0.00001 & 23384 \\
\hline L0226 & $5 / 22 / 1997$ & 19 CU YD ROLL OFF PAN & 2150.1 & 6.6838 & 25534 & 0.00001 & 23384 \\
\hline L0227 & $5 / 22 / 1997$ & 19 CU YD ROLL OFF PAN & 2150.1 & 6.6838 & 25534 & 0.00001 & 23384 \\
\hline L0228 & $5 / 29 / 1997$ & 19 CU YD ROLL OFF PAN & 2150.1 & 6.6838 & 25534 & 0.00001 & 23384 \\
\hline L0229 & $5 / 29 / 1997$ & 19 CU YD ROLL OFF PAN & 2150.1 & 6.6838 & 25534 & 0.00001 & 23384 \\
\hline
\end{tabular}




\begin{tabular}{|c|c|c|c|c|c|c|c|}
\hline L0230 & $5 / 29 / 1997$ & 19 CU YD ROLL OFF PAN & 2150.1 & 6.6838 & 25534 & 0.00001 & 23384 \\
\hline L0231 & $5 / 29 / 1997$ & 19 CU YD ROLL OFF PAN & 2150.1 & 6.6838 & 25534 & 0.00001 & 23384 \\
\hline L0232 & $5 / 29 / 1997$ & 19 CU YD ROLL OFF PAN & 2150.1 & 6.6838 & 25534 & 0.00001 & 23384 \\
\hline L0234 & 6/2/1997 & 19 CU YD ROLL OFF PAN & 2150.1 & 6.6838 & 25534 & 0.00001 & 23384 \\
\hline L0235 & 6/2/1997 & 19 CU YD ROLL OFF PAN & 2150.1 & 6.6838 & 25534 & 0.00001 & 23384 \\
\hline L0236 & 6/2/1997 & 19 CU YD ROLL OFF PAN & 2150.1 & 6.6838 & 25534 & 0.00001 & 23384 \\
\hline L0237 & 6/2/1997 & 19 CU YD ROLL OFF PAN & 2150.1 & 6.6838 & 25534 & 0.00001 & 23384 \\
\hline L0239 & $6 / 3 / 1997$ & 19 CU YD ROLL OFF PAN & 2150.1 & 6.6838 & 25534 & 0.00001 & 23384 \\
\hline L0240 & 6/3/1997 & 19 CU YD ROLL OFF PAN & 2150.1 & 6.6838 & 25534 & 0.00001 & 23384 \\
\hline L0241 & $6 / 3 / 1997$ & 19 CU YD ROLL OFF PAN & 2150.1 & 6.6838 & 25534 & 0.00001 & 23384 \\
\hline L0242 & 6/3/1997 & 19 CU YD ROLL OFF PAN & 2150.1 & 6.6838 & 25534 & 0.00001 & 23384 \\
\hline L0243 & 6/4/1997 & 19 CU YD ROLL OFF PAN & 2150.1 & 6.6838 & 25534 & 0.00001 & 23384 \\
\hline L0244 & 6/4/1997 & 19 CU YD ROLL OFF PAN & 2150.1 & 6.6838 & 25534 & 0.00001 & 23384 \\
\hline L0245 & 6/4/1997 & 19 CU YD ROLL OFF PAN & 2150.1 & 6.6838 & 25534 & 0.00001 & 23384 \\
\hline L0246 & 6/4/1997 & 19 CU YD ROLL OFF PAN & 2150.1 & 6.6838 & 25534 & 0.00001 & 23384 \\
\hline L0247 & 6/4/1997 & 19 CU YD ROLL OFF PAN & 2150.1 & 6.6838 & 25534 & 0.00001 & 23384 \\
\hline L0248 & $6 / 5 / 1997$ & 19 CU YD ROLL OFF PAN & 2150.1 & 6.6838 & 25534 & 0.00001 & 23384 \\
\hline L0249 & $6 / 5 / 1997$ & 19 CU YD ROLL OFF PAN & 2150.1 & 6.6838 & 25534 & 0.00001 & 23384 \\
\hline L0250 & $6 / 5 / 1997$ & 19 CU YD ROLL OFF PAN & 2150.1 & 6.6838 & 25534 & 0.00001 & 23384 \\
\hline L0251 & 6/5/1997 & 19 CU YD ROLL OFF PAN & 2150.1 & 6.6838 & 25534 & 0.00001 & 23384 \\
\hline L0252 & $6 / 5 / 1997$ & 19 CU YD ROLL OFF PAN & 2150.1 & 6.6838 & 25534 & 0.00001 & 23384 \\
\hline L0253 & 6/10/1997 & 19 CU YD ROLL OFF PAN & 2150.1 & 6.6838 & 25534 & 0.00001 & 23384 \\
\hline L0254 & 6/10/1997 & 19 CU YD ROLL OFF PAN & 2150.1 & 6.6838 & 25534 & 0.00001 & 23384 \\
\hline L0255 & 6/10/1997 & 19 CU YD ROLL OFF PAN & 2150.1 & 6.6838 & 25534 & 0.00001 & 23384 \\
\hline L0256 & 6/10/1997 & 19 CU YD ROLL OFF PAN & 2150.1 & 6.6838 & 25534 & 0.00001 & 23384 \\
\hline L0259 & 6/10/1997 & 19 CU YD ROLL OFF PAN & 2150.1 & 6.6838 & 25534 & 0.00001 & 23384 \\
\hline L0260 & 6/10/1997 & 19 CU YD ROLL OFF PAN & 2150.1 & 6.6838 & 25534 & 0.00001 & 23384 \\
\hline L0261 & 6/10/1997 & 19 CU YD ROLL OFF PAN & 2150.1 & 6.6838 & 25534 & 0.00001 & 23384 \\
\hline L0098 & 2/26/1997 & 19 CU YD ROLL OFF PAN & 2150.1 & 6.6838 & 25534 & 0.01 & 23384 \\
\hline L0107 & $3 / 5 / 1997$ & 19 CU YD ROLL OFF PAN & 2150.1 & 6.6838 & 25534 & 0.005 & 23384 \\
\hline L0110 & 3/5/1997 & 19 CU YD ROLL OFF PAN & 2150.1 & 6.6838 & 25534 & 0.005 & 23384 \\
\hline L0123 & $3 / 11 / 1997$ & 19 CU YD ROLL OFF PAN & 2150.1 & 6.6838 & 25534 & 0.005 & 23384 \\
\hline L0153 & 3/20/1997 & 19 CU YD ROLL OFF PAN & 2150.1 & 6.6838 & 25534 & 0.002 & 23384 \\
\hline L0167 & 4/1/1997 & 19 CU YD ROLL OFF PAN & 2150.1 & 6.6838 & 25534 & 0.002 & 23384 \\
\hline L0176 & $4 / 2 / 1997$ & 19 CU YD ROLL OFF PAN & 2150.1 & 6.6838 & 25534 & 0.002 & 23384 \\
\hline L0190 & 4/17/1997 & 19 CU YD ROLL OFF PAN & 2150.1 & 6.6838 & 25534 & 0.002 & 23384 \\
\hline L0198 & $5 / 12 / 1997$ & 19 CU YD ROLL OFF PAN & 2150.1 & 6.6838 & 25534 & 0.002 & 23384 \\
\hline L0210 & $5 / 15 / 1997$ & 19 CU YD ROLL OFF PAN & 2150.1 & 6.6838 & 25534 & 0.00001 & 23384 \\
\hline L0233 & 6/2/1997 & 19 CU YD ROLL OFF PAN & 2150.1 & 6.6838 & 25534 & 0.00001 & 23384 \\
\hline L0238 & 6/3/1997 & 19 CU YD ROLL OFF PAN & 2150.1 & 6.6838 & 25534 & 0.00001 & 23384 \\
\hline L0257 & 6/10/1997 & 19 CU YD ROLL OFF PAN & 2150.1 & 6.6838 & 25534 & 0.00001 & 23384 \\
\hline L0046 & $1 / 28 / 1997$ & 19 CU YD ROLL OFF PAN & 2150.1 & 6.6838 & 25534 & 0.06 & 23384 \\
\hline L0058 & 2/4/1997 & 19 CU YD ROLL OFF PAN & 2150.1 & 6.6838 & 25534 & 0.06 & 2338 \\
\hline L0061 & 2/6/1997 & 19 CU YD ROLL OFF PAN & 2150.1 & 6.6838 & 25534 & 0.05 & 2338 \\
\hline L0070 & 2/11/1997 & 19 CU YD ROLL OFF PAN & 2150.1 & 6.6838 & 25534 & 0.05 & 2338 \\
\hline L0258 & 6/10/1997 & 19 CU YD ROLL OFF PAN & 2150.1 & 6.6838 & 25534 & 0.00001 & 233 \\
\hline
\end{tabular}

